\title{
The impact of the Bankruptcy Abuse Prevention and Consumer Protection Act of 2005 Repo 'Safe harbor' provisions on investors
}

\author{
Chircop Justin* \\ Lancaster University Management School \\ Fabrizi Michele \\ University of Padua \\ Parbonetti Antonio \\ University of Padua
}

\section{*Corresponding Author}

Department of Accounting and Finance,

Lancaster University Management School,

Lancaster University,

Lancaster, UK LA1 4YX

j.chircop1@lancaster.ac.uk

Tel: +44 (0)1524 594634 


\title{
The impact of the Bankruptcy Abuse Prevention and Consumer Protection Act of 2005 Repo 'Safe harbor' provisions on investors
}

\begin{abstract}
The Bankruptcy Abuse Prevention and Consumer Protection Act (BAPCPA) of 2005 significantly expanded the exemptions from the normal workings of the U.S. Bankruptcy Code. Using a large sample of U.S. banks, we study investors' reaction to news about the promulgation of the BAPCPA repo 'safe harbor' provisions and the influence extending such exemptions to repos collateralized by riskier collateral had on equity market information asymmetry. We find a negative market reaction to news events about the promulgation of BAPCPA, which subsequent cross-sectional analysis suggests is at least partly driven by repo exposure. This finding suggests that investors perceived the increase in finance risk from the extension of the 'safe harbor' provisions as dominating the perceived gain from accessing cheaper finance. Further, we find that the promulgation of BAPCPA gave rise to increased information asymmetry for banks with repo exposure.
\end{abstract}

Keywords: Repurchase agreements; Bankruptcy Code; Safe harbor

Data Availability: Data used in this study are available from the public sources identified in the study.

JEL Classification: M41, G21, G32 


\section{The impact of the Bankruptcy Abuse Prevention and Consumer Protection Act of 2005 Repo 'Safe harbor' provisions on investors}

\section{Introduction}

We analyze the equity market reaction to the promulgation of the Bankruptcy Abuse Prevention and Consumer Protection Act (BAPCPA) of 2005 and banks' market information asymmetry following the extension of the "safe harbor" provisions to repurchase agreements (repos) collateralized by risky assets. 'For most financial institutions that actively trade in the debt markets on a day-to-day basis, cash needs are met by borrowing through repurchase agreements' (Krishnamurthy 2010, 8). This establishes the repo market as one of the main sources for the provision of short-term wholesale funding. Given insufficient information about bilateral repo agreements, there are no estimates of the actual size of the total U.S. repo market. Rough estimates of the amount of repo transactions entered by U.S. primary dealers suggest that repos are a significant source of finance. Specifically, data derived from Federal Reserve's Form FR 2004, suggests that in 2015 U.S. primary dealers ${ }^{1}$ entered around $\$ 2.2$ trillion of repos (Baklanova 2015).

The importance and growth of the repo market can at least be partly attributed to its preferential treatment under bankruptcy law, resulting from the so-called 'safe harbor' provisions. These provisions which first appeared for repo agreements in the 1984 amendments

\footnotetext{
${ }^{1}$ As of August 2015, the following institutions were designated as primary dealers: Bank of Nova Scotia, New York Agency, BMO Capital Markets Corp., BNP Paribas Securities Corp., Barclays Capital Inc., Cantor Fitzgerald \& Co., Citigroup Global Markets Inc., Credit Suisse Securities (USA) LLC, Daiwa Capital Markets America Inc., Deutsche Bank Securities Inc., Goldman, Sachs \& Co., HSBC Securities (USA) Inc., Jefferies LLC, J.P. Morgan Securities LLC, Merrill Lynch, Pierce, Fenner \& Smith Incorporated, Mizuho Securities USA Inc., Morgan Stanley \& Co.LLC, Nomura Securities International, Inc., RBC Capital Markets, LLC, RBS Securities Inc., SG Americas Securities, LLC, TD Securities (USA) LLC, and UBS Securities LLC.
} 
to the Bankruptcy Code ${ }^{2}$ 'exempt the bankrupt debtor's financial-contract counterparties from the base rules that halt creditor collection efforts when the bankruptcy begins, and claw back preferential and fraudulent pre-bankruptcy transfers that harm creditors overall, thus facilitating an orderly liquidation or reorganization' (Morrison et al. 2014, 1016). As further discussed in the following sections, over the years these exemptions have been extended to encompass a variety of repo agreements.

Previous research has raised various concerns about the repo market with Gorton and Metrick (2010) describing the recent financial crisis as a 'run on repo'. In this regard, 'lenders of funds, worried about the value of collateral as well as the credit risk of counterparties, became increasingly concerned about losses on repurchase agreements' (Fleming et al. 2009, 2). In view of this, various authors have questioned whether repo agreement 'safe harbor' provisions have exacerbated the run on the repo market and whether thus, such exemptions should at least be narrowed (e.g. Lubben 2009; Roe 2011; Duffie and Skeel 2012).

Similarly, various authors have questioned whether the accounting for such transactions is adequate (Chircop et al. 2012) and whether disclosures on such transactions adequately inform shareholders about the riskiness of these transactions. In this regard, Adrian et al. (2012) conclude that it is particularly difficult to determine the risks arising from repo transactions entered by a specific firm. The Financial Accounting Standards Board (FASB) has recently noted stakeholder concern 'about the need to improve existing disclosure requirements for repurchase agreements, linking those needs to the credit crisis and the need to better understand the nature of these transactions, the use of funding obtained through these transactions, and the associated credit and liquidity risks' (FASB 2013).

\footnotetext{
2 The Bankruptcy Amendments and Federal Judgeship Act of 1984 extended 'safe harbor' provisions to repo agreements. This bill was signed into law on July 10, 1984.
} 
To explore the effect of 'safe harbor' exemptions on shareholders and on the overarching information asymmetries that plagues repos we focus on a particular amendment to the US bankruptcy statute brought about by the enactment of the Bankruptcy Abuse Prevention and Consumer Act of 2005. This Act significantly increased the array of repo agreements which could avail of the 'safe harbor' exemptions. Particularly the Act makes repos collateralized by risky collateral, such as mortgage backed securities, eligible for such exemptions. By expanding the scope of the 'safe harbor' exemptions, the Bankruptcy Code makes this source of financing more attractive to companies. Therefore, the BAPCPA exemptions likely resulted in a substitution effect where long-term sources of finance are substituted by cheaper short-term repo agreements. Exploiting this change in regulation, we analyze investor market reaction to news about the promulgation of the BAPCPA and the resulting changes in bank information asymmetry.

We acknowledge that the BAPCPA made several significant changes to the U.S. Bankruptcy Code including to force borrowers to move from Chapter 7, bankruptcy filing, to Chapter 11, reorganization. However, prior literature (e.g. Ayotte and Skeel 2013; Duffie and Skeel 2012; Infante 2012; Roe and Tung 2013) purports that the new rules on repo transactions included in the Act played a particularly important role and deeply affected the banking sector.

One of the challenges to our empirical analyses consists in isolating the impact of the repo 'safe harbor' provisions from the impact of other contemporaneous regulatory changes introduced by the BAPCPA on investor market reaction. To mitigate such concern, we benchmark our results to banks without any repo exposure and control for several bank specific characteristics that likely affect repo exposure. These analyses are particularly important in our research design since they allow us to link the investors' market reaction to the bank's repo exposure, thereby providing some confidence that the market effect documented throughout the paper is not capturing a general effect due to the introduction of the BAPCPA. 
The widening of the repo 'safe harbor' provisions likely influences investor market reaction because of two offsetting factors. The substitution of long-term financing with cheaper shorter-term collateralized financing reduces bank finance costs and should be perceived positively by shareholders (finance cost factor). Offsetting this effect is the increased finance risk $^{3}$ the company exposes itself to by substituting stable long-term sources of finance with mostly overnight repo agreements. This is likely to be perceived negatively by shareholders (finance risk factor). In our analyses, we find negative market reactions to news about the promulgation of the BAPCPA suggesting that the finance risk factor dominates any benefit derived from the reduction in finance costs. A common limitation of such event studies is the identification of a control group to control for confounding events not related to the regulatory change under study. To address this limitation, we use banks without any repo exposure during our sample period as our control and find that the observed negative market reaction is statistically significant for banks with repo exposure only. While such an analysis allows us to control for confounding events, there is still the possibility that the observed results are due to the effect of changes in bankruptcy law on bank characteristics correlated with repo exposure. To control for such possibility, in subsequent cross-sectional analyses we control for firm characteristics which prior literature have shown to be related to repo exposure and, find that the previously observed market reaction is at least partly driven by repo exposure.

Given that the widening of the 'safe harbor' provisions brought about by the BAPCPA expanded the heterogeneity of repo transactions, and this change was not accompanied by enhanced disclosures, it is likely that it caused an increase in market information asymmetry. We measure information asymmetry using equity market bid-ask spreads. Using a difference-

\footnotetext{
${ }^{3}$ Finance risk is sometimes referred to as roll-over risk. It is the risk that repo financing is not rolled over on maturity. Moreover, repos expose companies to counterparty risk. This risk refers to the possibility that the counterparty either fails to satisfy margin calls or fails to honour the agreement to repurchase the underlying assets.
} 
in-differences approach, which controls for heterogeneity in the sampled banks, we find that following the enactment of the BAPCPA of 2005 the bid-ask spreads increased for banks with repo exposure when compared to a control group of banks with no repo exposure. To increase the likelihood that the treatment group is orthogonal with respect to the outcome variable we identify banks involved in repo transactions before the passage of the BAPCPA of 2005 and use banks that were not involved in repo transactions before and after the passage of the BAPCPA of 2005 as our control group. Moreover, we undertake tests to show that the treated and control groups satisfy the parallel trend assumption prior to the enactment of the BAPCPA of 2005. Finally, we employ bank fixed effects to mitigate concerns about the heterogeneity between banks with repo and without repo transactions. ${ }^{4}$

Our paper contributes to two streams of literature. First, we contribute to the literature analyzing the effects of the BAPCPA of 2005 expansion of the repo agreements 'safe harbor' provisions. While the repercussions of such changes on the incentives of creditors and on the functionality of the normal Bankruptcy Code procedures have been thoroughly discussed (e.g. Lubben 2009; Roe 2011; Duffie and Skeel 2012), this is to our knowledge the first study that examines the economic consequences of this change in bankruptcy law from a shareholder perspective. Specifically, to assess whether the expected benefits of the new regulation were outweighed by unexpected costs due to finance risk we study shareholder reaction to events leading to the propagation of the BAPCPA, and capital market effects in the aftermath of the BAPCPA becoming effective. Secondly, we add to the literature on the effects of the BAPCPA by showing that the increased heterogeneity of repurchase agreements arising from the widening of the type of collateral exempted from the 'automatic stay' gave rise to increased

\footnotetext{
${ }^{4}$ We acknowledge that the ideal control group for our difference-in-differences analysis would be composed of banks to which all regulations except for the BAPCPA regulations relating to repo transactions apply. This control group does not exist since all US banks fall within the scope of the BAPCPA.
} 
information asymmetry. This is an important unintended capital market effect of the BAPCPA arising from changes in the legal framework which are not accompanied by changes in the disclosure requirements set out in accounting regulation. In this way, we add to the literature examining the consequences of asynchronous changes in company regulations and we contribute to prior research that highlights the necessity of close coordination between different sets of accounting and bank regulation (e.g. Cerbioni et al. 2015; Fabrizi and Parbonetti 2015). We feel that this is the main policy implication of our study.

This study is structured as follows: Section 2 sets out the institutional background and discusses extant literature relevant to this study. Section 3 discusses the major congressional news events leading to the passage of the BAPCPA of 2005 while Section 4 sets out our hypotheses. Section 5 discusses the research design, sample and empirical results relating to the market event and subsequent cross-sectional analyses. Similarly, Section 6 discusses the research design, sample and empirical results relating to the information asymmetry analyses. Section 7 concludes.

\section{Background and Literature Review}

\subsection{Institutional background}

Repos are two-legged transactions which combine a spot market sale with a simultaneous forward agreement to repurchase the underlying instrument at a later date, often the next day (Duffie 1996, 497). The party undertaking the spot market sale of the underlying instruments is said to be entering into a repo transaction, while the party purchasing the underlying instruments while simultaneously agreeing 'to resell the same or equivalent securities at a specific price at a later date' (Ong and Yeung 2011), is said to be undertaking a reverse repo transaction. Moreover, since each leg of the transaction is a true sale, it is often ${ }^{5}$

\footnotetext{
${ }^{5}$ Sometimes provisions are inserted in the repurchase agreement which prohibits the sale and/or rehypothecation of the collateral to third parties.
} 
the case that the party acquiring the underlying financial instruments may sell or rehypothecate such collateral to third parties.

The repo market plays an important role in the efficient allocation of capital (Fleming et al. 2009). Banks and dealers 'use repurchase transactions to finance inventories, to cover short positions, to create leverage and to hedge or speculate on interest rate movements' while pension funds and insurance companies use repos 'to invest surplus cash, to earn incremental returns on their portfolios or to raise cash for investment' (Hördahl and King 2008, 38).

In 2005 when the Bankruptcy Abuse Prevention and Consumer Protection Act (BAPCPA) was signed into law, accounting for repurchase agreements was regulated by SFAS $140^{6}$ which set out the repo transaction disclosure requirements in $\$ 17$ (FASB 2000). SFAS 140 required an entity entering into a repo agreement:

1) to disclose 'its policy for requiring collateral or other security';

2) if the entity has pledged any of its assets as collateral that are not reclassified and separately reported in the statement of financial position...' it should disclose '...the carrying amounts and classifications of those assets as of the date of the latest statement of financial position presented';

3) 'if the entity has accepted collateral that is permitted by contract or custom to sell or repledge, the fair value as of the date of each statement of financial position presented of that collateral and of the portion of that collateral that it has sold or repledged, and information about the sources and use of that collateral' (FASB $2000 \S 17)$.

\footnotetext{
${ }^{6}$ SFAS 140, 'Accounting for Transfers and Servicing of Financial Assets and Extinguishments of Liabilities' was issued in September 2000. It was amended by SFAS 166 (FASB, 2009) 'Accounting for Transfers of Financial Assets an amendment of FASB Statement No. 140' and more recently FASB issued Accounting Standard Updated (ASU) 2014-11 Transfers and Servicing (Topic 860) (FASB,2014) 'Repurchase-to Maturity Transactions, Repurchase Financings, and Disclosures' which expand disclosures on repurchase agreements.
} 
The significance of the repo market as a source of short-term funding for banks and the fact that the repo market is opaque to most financial statement users makes disclosures about banks' exposure to the repo market especially important for financial statement users to be able to price bank risk.

\subsection{Literature review}

One of the most important objectives of Bankruptcy legislation is to set priority rules, which are central to business reorganizations. Specifically, based on these rules value is distributed among creditors by the bankrupt firm. The importance of such rules is highlighted by the fact that a firm in bankruptcy lacks sufficient value to honor all its obligations, and thus priority rules ultimately determine which of the firm creditors are to be paid (Roe and Tung 2013).

The importance of such priority rules, have resulted in different creditors, among which parties to the repo market, lobbying the U.S. Congress to achieve super-priority in bankruptcy proceedings. This super-priority alters bankruptcy distributions, where payment to certain creditors is prioritized to the detriment of other firm creditors. Specifically, the Bankruptcy Code exemption of repos from automatic stay incentivizes creditors supplying collateralized loans to undertake repo agreements. Indeed, while the automatic stay typically prohibits the immediate liquidation of the collateral in favor of the loan, repos are exempt from such stay and thus repo creditors can in the event of a bankruptcy event, immediately liquidate any collateral (Ibid.). In other words, such exemption allows for the resolution of repo obligations out of the bankruptcy court proceedings.

The primary argument for the introduction of these exemptions is that the repo market is major source of systemic risk and that such exemptions help in reducing such risk (Bliss and Kaufman 2006). Systemic risk is the risk that major financial institutions fail at the same time 
resulting in market illiquidity. The costs and benefits of these exemptions have been the subject of various studies. For example, Edwards and Morrison (2005) examine the effect the exemptions from 'automatic stay' afforded to derivative and repo contracts had on the collapse of hedge fund Long Term Capital Management (LTCM) in the Fall of 1998. They conclude that the exemptions afforded to derivative and repo contracts by the Bankruptcy Code not only failed to reduce systemic risk, but exacerbated such risk, forcing the Federal Reserve to intervene and support LTCM. Specifically, the authors suggest that in a forced liquidation, the exemption of derivative and repo contract counterparties from 'automatic stay' would have enabled these counterparties to close-out and seize LTCM assets to the detriment of other creditors. This "would not only have [had] a significant distorting impact on market prices, but also in the process could produce large losses - or worse - for a number of creditors and counterparties, and for other market participants who were not directly involved with LTCM..." (Greenspan 1998).

More recently, Roe (2011) examines the failure of AIG, Bear Stearns and Lehman Brothers within the ambit of the exemptions afforded by the Bankruptcy Code to derivative and repo counterparties. By exempting derivative and repo counterparties from the normal bankruptcy proceedings, the Bankruptcy Code gives preference to these parties over other creditors. Such preference waters down the market discipline incentives for prioritized creditors and enhances the market discipline incentives for nonprioritized creditors. Notwithstanding this, nonprioritized creditors, such as the US tax payer, are poorly positioned to replicate the degree of counterparty market discipline that would have been afforded by prioritized creditors. The author concludes that the reduced incentives for repo counterparties to monitor their debtors likely contributed to the recent collapse of major financial institutions.

Preferential treatment of repo counterparties also contributes to the inefficient substitution of funding away from traditional sources of finance (Duffie and Skeel 2012). This 
cost stems from the fact that the exemption from automatic stay makes short term repo financing cheaper when compared to traditional finance. Indeed, suppliers of traditional finance will likely charge higher interest rates than repo finance in response to the increase default losses arising from the loss of priority to repos (Bolton and Oehmke 2015). Such a cost is particularly pertinent, given that repo financing is a fragile source of finance, typically consisting of transactions with overnight maturities which must be rolled over every day. Given this, such financing might easily be withdrawn by counterparties (Gorton and Metrick 2012).

Besides the above mentioned costs, the repo exemption from automatic stay also has a number of benefits, the most sizeable of which is that it discourages repo counterparties from running on the firm as soon as the firm's financial condition is suspect. This given that the repo exemption from automatic stay gives added flexibility to repo counterparties to quickly exit a repo agreement, even after the initiation of bankruptcy proceedings (Duffie and Skeel 2012).

The Bankruptcy Abuse Prevention and Consumer Protection Act (BAPCPA) of 2005, the legislation at the center of this study and which we discuss further in the next section, expanded the range of repurchase agreements that could avail from the exemption from automatic stay. There is a paucity of literature examining the effect of the BAPCPA at the firm level. An exception to this, is Ganduri (2017) who studies the impact of the 2005 bankruptcy reform act on mortgage origination by Mortgage Companies (IMCs). The study finds that postBAPCPA, IMCs increased the issuance of risky mortgages which ultimately resulted in an increase in ex-post defaults. The author attributes this IMC response to the availability of cheaper finance resulting from the increased creditor protection offered by the BAPCPA. Our study complements Ganduri (2017) by examining the equity market effects of BAPCPA. While prior literature discussed previously has looked at the effects of changes in bankruptcy statute on financial institutions and their creditors, we are the first to examine the impact of the BAPCPA on investors. Examining the effect of the BAPCPA on the equity market is 
particularly important given that the equity market consists of public banks' ultimate owners, the shareholders.

\section{The Bankruptcy Abuse Prevention and Consumer Protection Act (BAPCPA) of} 2005

The enactment of the Bankruptcy Abuse Prevention and Consumer Protection Act (BAPCPA) significantly altered the US bankruptcy statue. Among other changes, by widening the array of repos that could take advantage of the 'safe harbor' exemptions, this legislation significantly altered the functioning of the US repo market. In Section 3.1 we provide a detailed overview of the effect of the BAPCPA on the repo market while in Section 3.2 we list the main events leading to the enactment of the BAPCPA.

3.1 The effect of Bankruptcy Abuse Prevention and Consumer Protection Act (BAPCPA) of 2005 on the repo market

A repo is a hybrid contract between a sale of securities and a secured loan (Stigum 1989). In the past, this hybrid nature led to uncertainty about whether the automatic stay should be applied if a repo borrower files for bankruptcy. In 1982, in the case of Lombard-Wall the court ruled that the securities purchased in a repo transaction were subject to the automatic stay. The sentence was contrary to market expectations and Stigum $(1989,219)$ quotes a market participant who said that the sentence "scared the hell out of the industry". As a consequence of the Lombard-Wall case, there was an effort to change the Bankruptcy Code exempting repo collateral from automatic stay. The Treasury department did not champion this change arguing that the exemption from automatic stay would reduce the oversight incentive of repo lenders over repo borrowers. However, in 1984 the Bankruptcy Code was amended providing a 'safe harbor' (the exemption from the automatic stay) to repos collateralized by treasury and agency securities, bank certificates of deposits and banker's acceptances. 
In the mid '90s repo financing was extended to riskier and non-traditional collateral such as mortgage backed securities and asset backed securities (Acharya et al. 2010). However, given that only "traditional" securities were exempted from automatic stay "repo contracts were written to represent the transaction as a true sale, so that if the borrower filed for bankruptcy, the lender could retain the possession of the securities" (Maclachlan 2014, 519). However, another court sentence ruling the bankruptcy of Criimi Mae in 2002 surprised market participants creating uncertainty in the repo market (Schroeder 2002). The court sentenced that the repo used by Criimi Mae was equivalent to a secured loan and that the collateral was not exempted from automatic stay. Similar to Lombard-Wall, this case, gave new impetus to amend the Bankruptcy Code to widen the 'safe-harbor' provision to include non-traditional securities. Indeed, the BAPCPA of 2005 widened the range of 'safe-harbored' repos. In this respect $\$ 907$ of the BAPCPA amended the definition of repurchase agreement in paragraph 47, Title 11, of the US Bankruptcy Code to include transfers of the following instruments:

- Mortgage related securities (as defined in Section 3 of the Securities Exchange Act of 1934).

- Mortgage loans.

- Interests in mortgage related securities or mortgage loans.

- Qualified foreign government securities (defined as a security that is a direct obligation of, or that is fully guaranteed by, the central government of a member of the Organization for Economic Cooperation and Development). ${ }^{7}$

The relevant Bankruptcy Code procedures which allow repurchase agreement counterparties exemptions from the normal bankruptcy proceedings are $\S 559$ which exempt repo agreement counterparties from the automatic stay, §362(b)(7) and §362(o), 'which protect

\footnotetext{
${ }^{7}$ Bankruptcy Abuse Prevention and Consumer Protection Act of 2005, Pub. L. No. 109-8, §907, 119 Stat. 23 , $171-72$
} 
repo counterparties' setoff rights and their rights to realize against margin or other collateral posted by the debtor' (Morrison et al. 2014, 1022) thus buttressing the exemption from automatic stay set out in $§ 559$, and $\$ 546(f)$ and $§ 548(d)$ "which shield repo counterparties from preferential or fraudulent transfer actions seeking to recover margin, settlement, or other payments made in connection with repo agreements" (Ibid., 1022).

\subsection{News Events Leading To The Passage Of The Bankruptcy Abuse Prevention}

And Consumer Protection Act (BAPCPA) Of 2005

The Bankruptcy Abuse and Consumer Protection Act (BAPCPA) of 2005 was a highly controversial piece of legislation which makes the most significant changes to the Bankruptcy Code since its enactment in 1978 (Benton, 2005). The main driver for the passage of this bill was the perceived ease by which petitioners (in particular individuals) could apply for and initiate bankruptcy procedures. "In 1979... debtors filed 225,000 individual petitions. By 2004, filings increased dramatically to more than 1.5 million petitions" (Ibid, CC1). In this regard, the main goal of the BAPCPA of 2005 was to prevent perceived abuse of the bankruptcy provisions by enforcing means testing and promoting credit counselling to incentivize borrowers with the ability to repay to move from Chapter 7 bankruptcy filing to Chapter 11 reorganization.

Given the controversial nature of this Act, its enactment was a long difficult process which saw its beginning in 1997 when it was first drafted. In December 2000, both Congress and the House of Representatives approved an amended draft titled Bankruptcy Reform Act of 2000, however President Clinton employed a 'pocket veto' and left this bill unsigned (Riechmann 2000).

From 2000 to 2005 there were various attempts to pass amended forms of this legislation through Congress but it was only on February 1, 2005 that the bill in its current 
format was introduced as S.256 in the Senate by Republican Senator Charles Grassely of Iowa in his name and that of seven original cosponsors. On February 9, 2005 the Chairman of the House Committee on the Judiciary, F. James Sensenbrenner Jr., for himself and 60 other cosponsors introduced an identical bill in the House of Representatives (H.R. 685). On March 10, 2005 the bill was passed through the Senate by a vote of 74 in favor and 25 against (Record Vote No.:44) and was subsequently passed through the House of Representatives on April 14, 2005 by a vote of 302 in favor and 126 against (Roll No.108). The bill was signed into law by President Bush on April 20, 2005 and most of its provisions took effect on October 17, 2005 (Dickerson, 2006). ${ }^{8}$

$<<$ Insert table 1 about here>>

\section{Hypotheses Development}

\subsection{Market Reaction}

The market reaction to news about the passage of the BAPCPA depends on the weighting bank shareholders place on two offsetting effects. As suggested by Duffie and Skeel (2012) an expansion of the type of collateral that could be used in repurchase agreements to avail from the 'safe harbor' provisions is likely to facilitate financing through the repo market thus facilitating firm growth. Moreover, given that the 'safe harbor' provisions for repo agreements essentially give preferential treatment to the repo market when compared to other funding markets, it is likely that financing through the repo market is cheaper than sourcing financing through other markets (Roe 2011; Duffie and Skeel 2012). These factors likely contributed to the continuing growth in the repo market as evident in Figure 1. Considering

\footnotetext{
${ }^{8}$ Vide Table 1 for the major Congressional events in 2005 that led to the passage of the Bankruptcy Abuse and Consumer Protection Act (BAPCPA) of 2005.
} 
these effects, we would expect equity market participants to have viewed news about the passage of the BAPCPA positively. We call this effect the finance cost factor.

$<<$ Insert Figure 1 about here>>

The finance cost factor is likely offset by the finance risk factor. The latter factor arises from the incentive provided by the BAPCPA to substitute more stable long-term financing with short-term runnable repo financing (Duffie and Skeel 2012). In a similar vein, given that lenders have a preference to provide longer-term financing against higher quality collateral and that the widening of the scope of the 'safe harbor' provisions set out by the BAPCPA facilitate the use of riskier collateral, it is likely that the BAPCPA resulted in an incentive to substitute term repo with overnight repo transactions (Gorton and Metrick 2012). As shown in Figure 2, after the BAPCPA became effective overnight repos comprised an increasing percentage of total repos. As shown in Figure 3 this is possibly due to the increasing use of riskier collateral in repo transactions following the promulgation of the BAPCPA. Such changes in the financing arrangements of banks likely increase bank finance risk (Gorton and Metrick 2009; 2012). The market perception that the promulgation of the BAPCPA will increase bank finance risk would give rise to a negative market reaction to any news increasing the probability of the passage of the BAPCPA.

<<Insert Figure 2 and Figure 3 about here>>

It is unclear what weighting investors attribute to each factor. Market participants attributing a higher weighting to the finance cost factor would have a positive market reaction to news increasing the probability of enacting the BAPCPA. Conversely, we would expect negative reactions to these news events if investors attribute a higher weight to the finance risk factor. Given that ex-ante we do not have a prediction as to which factor will dominate we express our first hypothesis in its null form: 


\section{H1: There is no equity market reaction to news about the passage of the BAPCPA.}

\subsection{Information Asymmetry}

There is a rich literature examining the role of company disclosures in mitigating the agency conflict between shareholders and management (Leftwich 1980; Watts and Zimmerman 1986; Beaver 1998). Specifically, this literature finds that "financial reporting and disclosure are potentially important means for management to communicate firm performance and governance to outside investors" (Healy and Palepu 2001, 405). Since the widening of the 'safe harbor' provisions to different types of collateral likely expanded the heterogeneity of repo transactions, and this change was not accompanied by enhanced disclosures about the type of repo transactions undertaken by banks, we posit that the BAPCPA caused an increase in equity market information asymmetry. We express our second hypothesis as follows:

\section{H2: The BAPCPA increased equity market information asymmetry for banks undertaking repurchase agreements.}

\section{Market reaction}

5.1 Variable measurement and research design

Our study infers investor perceptions to the BAPCPA by examining equity market reactions to events leading to the promulgation of the said regulation. In this respect, we follow a similar approach to prior studies which have examined investor perceptions to new regulations. This approach entails first determining the abnormal return for a three-day event window using a multifactor model controlling for market returns and change in treasury rates, and subsequently regressing this abnormal return on firm specific characteristics to determine which firm characteristics explain the observed abnormal returns. Prior literature using a 
similar approach to ours include Beatty et al. (1996) who study investor perceptions to the promulgation of fair value accounting; Dechow et al. (1996) who study investor perceptions to stock based compensation accounting; Jain and Rezaee (2006), Zhang (2007) and Li et al. (2008) who study investor perceptions to the Sarbanes Oxley Act and Armstrong et al. (2010) who study investor perceptions to the adoption of IFRSs in Europe.

Though popular in prior literature there are various alternatives to the methodology used in this study. For example Brown and Warner (1980) have proposed the following three different methods how to calculate abnormal returns when event dates are known: 1) mean adjusted returns, 2) market adjusted returns and 3) market and risk adjusted returns. Dyckman et al. (1984) and Brown and Warner (1985) assess the accuracy of these different event study methodologies when daily returns are used and find that the different measures of abnormal returns perform similarly. Chandra et al. (1990) re-examine the Brown and Warner (1985) results and conclude that the market- and market-and risk- adjusted return methodology perform better than the mean-adjusted return methodology. They conclude that the strong performance of the mean-adjusted return methodology in the Brown and Warner (1985) study is a statistical artifact. Finally, Brown and Weinstein (1985) examine abnormal returns produced using multifactor models and conclude that multifactor models perform better than the one factor market model provided that the multifactor model is correctly specified. Given the above literature, Binder $(1998,122)$ concludes that if the sample consists of firms from unrelated industries, the one factor market model "works at least as well as the alternatives". Given that the sample for this study consists exclusively of banks, we calculate abnormal returns using a multifactor model which apart from controlling for market returns, also controls for changes in interest rates. For the banking industry, a change in interest rates has a direct impact on what banks charge borrowers and what banks pay for funding (Noonan, 2017). 
Another alternative to the Beatty et al. (1996) model would be an event study that computes cumulative abnormal returns around each event date and then regresses the abnormal returns for each event date separately on a vector of explanatory variables. This approach assumes that the event dates are independent of each other, and that different firm characteristics drive the abnormal returns observed on different event dates. We used the Beatty et al. (1996) approach because in our setting we have multiple event dates, all related to the enactment of the BAPCPA. In this ambit, the Beatty et al. (1996) methodology allows us to identify the bank characteristic which is on average driving abnormal returns for all the identified event dates.

In the first set of tests we investigate our first research hypothesis concerning the market reaction around news events that led to the passage of the BAPCPA. To do so, we begin with a multifactor model in which firm-specific returns are regressed on market return, on a variable capturing interest rate changes, and on an event indicator variable. The event indicator variable allows for mean shifts in returns on event days. For each company $i$, the following process is assumed to hold:

$$
R E T_{i t}=\beta_{1}+\beta_{2} M K T_{\_} R E T_{t}+\beta_{3} C H G_{-} T R E A S_{t}+\beta_{4} E V E N T \_A L L_{t}+\varepsilon_{i t}
$$

$R E T$ is daily stock price return for firm $i$ in day $t, M K T \_R E T$ is CRSP equally-weighted daily return, CHG_TREAS is the daily change in the Barclays US treasury index, and EVENT_ALL is an indicator variable that tags the event days listed in Table 1. We use a threeday event window ${ }^{9}$ to test for nonzero excess returns for the events listed in Table 1, i.e., the variable EVENT_ALL assumes a value of 1 on the day preceding, the day of, and the day after

\footnotetext{
${ }^{9}$ The use of three-day event windows is well established in the literature. For example, Bushee and Goodman (2007); Krishnamurthy et al. (2006); Pinnuck (2005) and Ali et al (2004) all use three-day time windows in their research design.
} 
the event dates (where days are defined as CRSP trading days). The sign and statistical significance of $\beta_{4}$ captures the average abnormal returns arising from events related to the passage of the BAPCPA.

Given that any observed market reactions in Equation 1 might be due to confounding events unrelated to the widening of the repo 'safe harbor' provisions, in subsequent analysis we use banks without repo exposure as our control group by interacting EVENT_ALL with an indicator variable which takes the value of 1 if the bank had any repo exposure during our sample period, and 0 otherwise. Such an approach allows us to control for any other changes implemented by BAPCPA which affect banks, but which are unrelated to repo exposure.

Even though the above approach allows us to control for confounding events, there is still the possibility that the observed market reactions are driven by other bank characteristics correlated with repo exposure. This concern is particularly pertinent given that as previously discussed the BAPCPA introduced significant changes in both personal and corporate bankruptcy law. To address this concern, we examine cross-sectional determinants of event market reactions. This test is based on the premise that the $R E P O$ variable is orthogonal to changes brought about by the BAPCPA except for the widening of repo 'safe harbor' provisions. To do so, we use a two-stage regression where in the first stage, we run Equation 1 for each bank in our sample over the sample period and in the second stage we regress the firmspecific coefficient obtained on the dummy EVENT_ALL, on a vector of bank characteristics to control for the heterogeneity of our sampled banks. Thus, Equation 2 is:

BETA $_{i}=\beta_{1}+\beta_{2} R E P O_{i}+\beta_{3} R E V_{-} R E P O_{i}+\beta_{4} M K T_{-} V A L_{i}+\beta_{5} D E R I V_{i}+\beta_{6} L O A N S \_R E A L_{i}+$ $\beta_{7} L O A N S \_D E P_{i}+\beta_{8} L O A N S \_A G R I C_{i}+\beta_{9} L O A N S \_C O M M_{i}+\beta_{10} L_{O A N S \_I N D}+$ $\beta_{11} L O A N S \_F O R E I G N_{i}+\beta_{12} S I_{i}+\beta_{13} N_{i}+\beta_{14} C A P I T A L \_R A T I O O_{i}+\varepsilon_{i}$ 
This equation is a purely cross-sectional test, where BETA is the firm-specific coefficient obtained on the indicator variable EVENT_ALL when estimating Equation 1 for each sampled bank and the explanatory variables are the mean values over the sample period. $R E P O$ is an indicator variable which takes the value of 1 if the bank engages in repo transactions, 0 otherwise; $R E V \_R E P O$ is an indicator variable which takes the value of 1 if the bank engages in reverse repo transactions, 0 otherwise $;{ }^{10} M K T_{-} V A L$ is the logarithm of market capitalization that controls for size; DERIV is the amount of derivatives; LOANS_REAL is the amount of loans secured by real estate; LOANS_DEP is the amount of loans to depository institutions; LOANS_AGRIC is the amount of loans to finance agricultural production; LOANS_COMM is the amount of commercial and industrial loans; LOANS_IND is the amount of loans to individuals; LOANS_FOREIGN is the amount of loans to foreign governments; SI is securitization income ${ }^{11} ; N I$ is net income ${ }^{12}$ and CAPITAL_RATIO is the bank's capital ratio ${ }^{13}$. All continuous variables with the exception of $M K T \_V A L$ and $C A P I T A L \_R A T I O$ are scaled by total assets. Further, all variables are computed as the average of the figures for the quarter ending December 31, 2004 and the quarter ending March 31, 2005. In order to control for the effect of outliers, all continuous variables are winsorized at the $1^{\text {st }}$ and $99^{\text {th }}$ percentile. ${ }^{14}$

In addition to Equation 2 we also implement the approach suggested by Sefcik and Thompson (1986). This methodology gives coefficients equal to the two-stage regression but yields valid standard errors since it accounts for heteroskedasticity and residual crosscorrelation which arise when events impact all sampled firms at the same time. Specifically, the two-stage regression model assumes homoscedasticity of residuals and the absence of

\footnotetext{
10 Another approach is to include net repurchase agreement (calculated as the difference between $R E P O$ and $R E V \_R E P O$ ) instead of including $R E P O$ and $R E V \_R E P O$ separately in our model. While such an approach would allow us to measure the association between net repo exposure and market reaction, it would average out the magnitude and direction of the association between both repo measures and the market reaction.

${ }^{11}$ Variable bhckb493 of the FRY-9C statements

12 Variable bhck4340 of the FRY-9C statements

${ }^{13}$ Variable bhck7205 of the FRY-9C statements

${ }^{14}$ In untabulated results we obtain the same inferences when we run the analyses without winsorizing the data.
} 
contemporaneous correlations across firms. The presence of time dependence in stock returns (Akgiray, 1989) and event-date clustering likely violate such assumptions in our research setting, thus resulting in biased coefficient estimates (Bernard 1987; Froot 1989; Kolari and Pynnonen 2010). To use the Sefcik and Thompson methodology, we create fourteen-weighted portfolio returns, one for each firm characteristic and the intercept, which we subsequently use as the dependent variables in Equation 2. To create the weighted-portfolio of returns we create two matrices: Matrix $\mathrm{R}$ is a $n \times j$ matrix, where $n$ is the number of trading days in our sample period and $j$ the number of firms and Matrix $\mathrm{F}$ is a $j \mathrm{x} k$ matrix, where $k$ consists of the thirteen different firm characteristics plus the intercept. Finally, the weighted-portfolio of returns is calculated as $\left(\mathrm{F}^{\prime} \mathrm{F}^{-1} \mathrm{~F}^{\prime} \mathrm{R}^{\prime}{ }^{15}\right.$

\subsection{Sample and data}

We obtain data on bank characteristics from the FR-9YC reports from the Federal Reserve Bank of Chicago and market data from CRSP. In order to estimate Equation 1 we use all trading days available on CRSP from January $1^{\text {st }}, 2005$ to April $30^{\text {th }}, 2005$ for all bank holding companies for which we can retrieve data on repo transactions from the FR-9YC reports. Importantly, to apply the Sefcik and Thompson (1986)'s adjustment, we require banks to have data for all trading days in our sample period in CRSP. These data requirements give us a final sample of 36,818 firm-day observations for 449 unique bank holding companies ${ }^{16}$.

\subsection{Empirical Results}

We use Equation 1 to examine market reactions to the major congressional news events in Table 1 leading to the passage of the BAPCPA. Table 2 provides distributional statistics of the variables used in Equation 1which shows a mean RET of $-0.1 \%$ over the sample period.

\footnotetext{
${ }^{15}$ Further detail on this approach is provided in Sefcik and Thompson (1986)

${ }^{16}$ Prior to data refinement that is based on the Sefcik and Thompson (1986) adjustment we have 459 unique bank holding companies. Thus, the use of the Sefcik and Thompson (1986) adjustment leads to the loss of 10 banks.
} 
The Pearson correlation matrix reported in Table 3 shows that variable EVENT_ALL is significantly negatively correlated with $R E T$, which suggests that the finance risk factor may have dominated the finance cost factor.

$<<$ Insert Table 2 and Table 3 about here>>

When we run Equation 1 for the 449 banks in our sample, in line with the results in Table 3, we find a statistically significant negative association between EVENT_ALL and RET. Specifically, column (1) in Table 4 shows that this association is significant at the $5 \%$ level. Given the wide scope of the sweeping changes brought about by the BAPCPA it is debatable to what extent such market reactions can be attributed to the provisions relating to repo agreements. To investigate the incremental effect having exposure to the repo market has on market reactions, we interact EVENT_ALL with REPO. Column (2) in Table 4 shows that the coefficient on the interaction term is negative and significant at the $1 \%$ level suggesting that the incremental effect of having repo exposure is highly negative. Furthermore, given that the main effect is insignificantly different from zero, the results suggest that only firms which undertake repos experience a negative market reaction to news increasing the probability that the BAPCPA is enacted, further suggesting that our results are driven by banks having exposure to the repo market.

When interpreting the results in the table, note that the single-event results reflect an average return during the event window. The overall sample's abnormal return can be obtained by multiplying each of these reported figures (i.e., the coefficients on EVENT_ALL) by the number of days in the event window (three days in our study). Column (1) shows that banks experienced an average -0.12 percent cumulative abnormal return during each three-day event window. Moreover, column (2) suggests that banks with repo exposure experienced an average incremental negative abnormal return of -0.42 percent during each three-day event window. 
<<Insert Table 4 around here〉>

To address the concern that the observed market reactions are driven by aspects of the BAPCPA other than the extension of the repo 'safe harbor' provisions we undertake a cross sectional analysis where we control for firm specific characteristics. Table 5 shows distributional statistics of the variables used in the cross-sectional analysis (Equation 2). 68.6\% of our sampled banks have repo exposure (REPO) while $11.6 \%$ undertake reverse repo transactions $\left(R E V \_R E P O\right)$. Our sampled banks have mean derivatives scaled by total assets $(D E R I V)$ of $12.3 \%$ and most of the loans are either loans secured by real estate (LOANS_REAL) or commercial and industrial loans $\left(L O A N S \_C O M M\right)$. Our proxy for securitization, SI is very small suggesting that most of our sampled banks do not undertake securitizations, while the mean CAPITAL_RATIO of our sampled banks is $13.9 \%$.

$<<$ Insert Table 5 around here >

The correlation matrix reported in Table 6 suggests that $R E P O$ is positively correlated with $R E V \_R E P O$ suggesting that firms undertaking repo transactions tend to also undertake reverse repo transactions. Moreover, both $M K T_{-} V A L$ and DERIV are positively correlated with $R E P O$ suggesting that larger firms and firms with derivative exposure undertake repo transactions. Interestingly, Table 6 shows a strong negative correlation between REPO and CAPITAL_RATIO suggesting that banks with repo exposure are weaker than their peers.

<<Insert Table 6 around here>>

Results for the two-stage regression reported in panel A of Table 7 show a statistically significant negative association between $R E P O$ and the market reaction coefficient, BETA. This result buttresses our prior results and suggests that firms with repo exposure had a more negative market reaction than firms without repo exposure. Interestingly, we find a statistically 
significant positive association between $R E V \_R E P O$ and $B E T A$ suggesting a positive market reaction for firms undertaking reverse repo transactions. This is possibly the result of the BAPCPA confirmation of the repo 'safe harbor' provisions, which enable providers of finance to the repo market exemptions from the normal bankruptcy procedures.

These inferences are confirmed when we control for heteroscedasticity and residual cross-correlation by adjusting returns using the Sefcik-Thompson methodology. As shown in panel $\mathrm{B}$ of Table 7, the negative association between $R E P O$ and $A d j \_R E T$ is statistically significant, further confirming that repo exposure is driving the observed negative returns around our event dates. Considering that the average value of BETA in our sample is -0.0004 , the coefficient in Table 7 on the variable $R E P O$ shows that banks with repo exposure experienced a market reaction that is twice as negative as the market reaction of banks without repo exposure, ceteris paribus. This result is consistent with estimates reported in Table 4.

\section{$<<$ Insert Table 7 around here $>$}

\section{$5.4 \quad$ Robustness tests}

As previously discussed, the presence of time dependence in stock returns (Akgiray, 1989) and the event-date clustering that occurs in our research setting likely result in the violation of the assumptions of homoscedasticity of residuals and the absence of contemporaneous correlations across firms on which the two-stage regression approach builds. Therefore, it is crucial for our study to correct for such biases. In the main analysis we used the Sefcik-Thompson methodology to correct for heteroscedasticity and residual cross-correlation, while in this section we explore alternative approaches to solve this issue and make sure that our results are not driven by specific research design choices. Specifically, to test for the sensitivity of our results to alternative approaches to correct for heteroscedasticity and cross- 
correlation we undertake the following three additional tests: 1) the Patell (1976) test, 2) the Boehmer et al. (1991) test, and 3) the Kolari and Pynnonen (2010) test.

Patell (1976) proposes a test statistic where the event period abnormal returns are standardized by the standard deviation of the estimation period abnormal return. This test is immune to the way in which abnormal returns are distributed across event windows but it is prone to cross-sectional correlation and event induced volatility. The Boehmer et al. (1991) test, apart from being immune to the way in which abnormal returns are distributed across event windows also adjusts for serial correlation and event induced volatility. Indeed, the Boehmer et al. (1991) test has gained popularity over the Patell (1976) statistic because it has been found to be more robust with respect to possible volatility changes associated with the event. Nonetheless, a weakness of this test is that it doesn't control for cross-sectional correlation. Finally, the Kolari and Pynnonen (2010) test is not only immune to the way in which abnormal returns are distributed over event windows, but it also adjusts for cross-sectional correlation. Specifically, Kolari and Pynnonen (2010) propose a new test statistic that modifies the Boehmer et al. (1991) t-statistic to take into account cross-correlation. Moreover, the Kolari and Pynnonen (2010) statistic is readily useable to test multiple-day cumulative abnormal returns.

As evident from Table 8, our results are statistically significant on the event date irrespective of which test is used, suggesting that the documented negative reaction around the even date is not driven by bias arising from event date clustering and that it is robust to different methodologies used to correct for heteroscedasticity and cross-correlation.

$<<$ Insert Table 8 around here>> 


\section{Information Asymmetry}

\subsection{Variable measurement and research design}

In our second set of tests we analyze whether the 'safe harbor' provisions brought about by the BAPCPA caused an increase in market information asymmetry. To do so, we employ a difference-in-differences approach where the treatment group consists of banks involved in repo transactions while the control group consists of banks that did not engage in repo transactions at any point during the sample period. To increase the likelihood that the treatment is orthogonal with respect to the outcome variable, we identify as treated banks those banks that at the end of 2004 (i.e. before the adoption of the BAPCPA) used repo transactions and that continue to use repos throughout our sample period. Thus, our analysis compares changes in information asymmetry before and after the BAPCPA adoption for banks exposed to repo transactions vis-à-vis banks that did not engage in repo transactions. Specifically, we employ the following multivariate regression model:

$S_{P P R_{i q+1}}=\beta_{1}+\beta_{2}$ POST $_{i q}+\beta_{3}$ TREATED $_{i q}+\beta_{4}$ POST $_{i q} *$ TREATED $_{i q}+\beta_{5}$ REV $_{-}$REPO $_{i q}+$ $\beta_{6} M K T \_V A L_{i q}+\beta_{7} D E R I V_{i q}+\beta_{8} L O A N S \_R E A L_{i}+\beta_{9} L O A N S \_D E P_{i}+\beta_{10} L O A N S \_A G R I C_{i}+$ $\beta_{11} L O A N S \_C O M M_{i}+\beta_{12} L O A N S \_I N D_{i}+\beta_{13} L O A N S \_F O R E I G N_{i}+\beta_{14} S_{i q}+\beta_{15} N_{i q}+$ $\beta_{16}$ CAPITAL_RATIO $O_{i q}+\varepsilon_{i q}$

where $S P R$ is the average bid-ask spread standardized by the average stock price. This measure is meant to proxy general equity market information asymmetry. SPR is computed quarterly and the estimation window runs from the quarter announcement date to the following quarter reporting date. POST is an indicator variable that takes the value of 1 for observations after the BAPCPA was enacted and 0 otherwise, while TREATED is an indicator variable that takes the value of 1 if the bank engaged in repo transactions before and after the BAPCPA was enacted 
(treatment group) and 0 otherwise (the control group). ${ }^{17}$ Thus, the interaction term between TREATED and POST provides a formal test for our second research hypothesis and tests whether information asymmetry among investors increased for banks exposed to repo transactions when compared to banks that do not undertake repo agreements.

\subsection{Sample and Data}

For our second set of analyses, we retrieve firm-quarter data from the FR-9YC reports for all bank holding companies with no missing data on repos for each quarter from 2004 to 2006. Since the BAPCPA was signed into law on April 20, 2005 but most of its provisions took effect on October 17, 2005, bank behavior in the second and third quarter of 2005 could be influenced by both the bankruptcy regulations effective at the time and the bankruptcy provisions applicable ones the BAPCPA is effective. Given that these two quarters are likely to be noisy, to attain a cleaner identification strategy to enable us to better compare bank behavior post-BAPCPA to bank behavior pre-BAPCPA, we drop from this analysis these quarters. Thus, we define the pre-period as consisting of the five quarters starting in first quarter of 2004 and ending in the first quarter of 2005 and the post period as consisting of the five quarters starting in the fourth quarter of 2005 and ending in the fourth quarter of $2005 .{ }^{18} \mathrm{Next}$, we merge data with CRSP and compute average bid-ask spread for each quarter. The final sample for this analysis consists of 3,137 firm-quarter observations for 374 unique banks. 1,217 firm-quarter observations are treated observations (i.e. banks with repo transactions at the end of 2004, and thereafter) and 1,920 are control observations (i.e. banks with no repo transactions throughout the sample period).

\footnotetext{
${ }^{17}$ We recognize that due to limited data availability we are unable to control for the type of repo agreements the company engages into. As previously discussed it is only after ASU 2014-11 became effective in 2015, that companies were required to disclose detailed information about the type of repo agreements they engage in.

${ }^{18}$ Given that the choice of the beginning and end of sample period is 'ad-hoc' in robustness tests we test for the sensitivity of our results to this research design choice.
} 


\subsection{Empirical Results}

Table 9 shows distributional statistics for the variables used in Equation 3 (both for treated and control observations, in Panels A and B respectively) while Table 10 presents the Pearson correlation matrix for the variables of interest. As evident from Table 9, treated banks (i.e. banks undertaking repo transactions) are larger (mean $M K T_{-} V A L$ of 14.052 vs 12.196) and more profitable (mean NI of 0.007 vs 0.006 ) than banks which do not undertake repo agreements. In terms of capital ratios, the two groups of banks are quite similar (mean CAPITAL_RATIO of 13.108 vs 13.895). The correlation matrix shown in Table 10 suggests that larger banks and banks with better performance have lower information asymmetry as evident by the negative correlation of $M K T_{-} V A L$ and $N I$ with $S P R$.

$<<$ Insert tables 9 and 10 around here>>

Table 11 formally tests the existence of a parallel trend between treated and control banks in the pre-adoption period, which is one of the underlying assumptions of the difference-indifferences model. To do so, we estimate model (3) by including interaction terms between the variable TREATED and dummy variables for each of the five pre-adoption periods (although not tabulated, interaction terms are also included for the post-period dummies). The existence of a parallel trend in the pre-adoption period requires that none of the interaction terms is statistically significant (we exclude the first interaction term and use it as benchmark group). Results reported in Table 11 support the existence of a parallel trend in the pre-adoption period as none of the interaction terms is statistically significant at conventional levels.

Having ascertained the existence of a parallel trend, Table 12 shows the results for Equation 3 where a differences-in-differences approach is used to analyze the effect of the BAPCPA on market information asymmetry. The coefficient of interest in Table 12 is the coefficient for $P O S T^{*} T R E A T E D$, which is statistically significantly positively associated with 
$S P R$, suggesting that following the passage of the BAPCPA firms exposed to repo agreements experienced an increase in bid-ask spreads when compared to the control group. The coefficient reported for $P O S T^{*} T R E A T E D$ in Table 12 shows that the increase in SPR after the passage of the BAPCPA is on average the 77 percent higher for banks exposed to repo agreements than for banks not exposed to repos. ${ }^{19}$

$<<$ Insert Table 12 around here>>

\subsection{Robustness tests}

In this section, we test whether our results are robust to changes in the empirical analysis. First, we investigate whether the documented increase in information asymmetry after the passage of the BAPCPA is sensitive to the number of quarters in the pre- and post-period used in the analysis. In Table 13, columns 1 and 2 we estimate Equation 3 using only four and three quarters in the pre- and post-period, respectively, and we document that our results are not sensitive to the choice of time window used in the analysis. In Table 13 column 3, we show the results when we adjust Equation 3 so that we control for bank size using the natural logarithm of total assets instead of market value, $M K T_{-} V A L$. These, results are similar to those previously reported. Next, in column 4 we change the estimation model and we use a generalized linear model (GLM) in place of an OLS model to estimate Equation 3 to gain asymptotic efficiency and obtain similar results to those reported in the main analysis. Finally, in the last column of Table 13 we winsorize all variables at $5 \%$ instead of $1 \%$, to make sure that outliers are not driving our results. As evident in Table 13, the interaction terms between POST and TREATED remains positive and statistically significant, thus corroborating the main findings.

$<<$ Insert Table 13 around here>>

\footnotetext{
${ }^{19}$ The economic significance is calculated as the coefficient on the interaction term $(0.0019)$ divided by the mean $S P R$ for the sample (0.00248).
} 


\subsection{Further analyses}

As discussed previously a major change brought about by the passage of the BAPCPA was to extend repo 'safe harbor' provisions to repo agreements collateralized by mortgagebacked securities. As banks with large holdings of mortgage backed securities are most likely to take advantage of the changes introduced by BAPCPA, as they can use such holdings as collateral in repo agreements, we expect companies with repo agreements and higher mortgage backed securities to experience higher information asymmetry following BAPCPA.

To test our prediction, we construct a variable $H I G H \_M B S$ which is a binary variable that takes the value of 1 for banks with amortized cost of mortgage backed securities scaled by total assets ${ }^{20}$ above median and 0 otherwise. We interact this variable with the dummy variable indicating the period post the passage of BAPCPA (POST) and a dummy variable identifying treated banks (TREATED). As shown in Table 14, the two-way interaction between POST and TREATED remains positive and statistically significant and the three-way interaction (POST*TREATED*HIGH_MBS) is statistically significantly positively associated with SPR indicating that the higher the mortgage backed security holdings, the higher is the increase in information asymmetry among investors for banks with repo exposure after the passage of BAPCPA.

$<<$ Insert Table 14 around here>>

Finally, we test whether empirical evidence supports our story that the widening of the repo 'safe harbor' provisions brought about by the BAPCPA incentivized banks to substitute long term stable financing with short term repo financing. Specifically, in this analysis we use

\footnotetext{
${ }^{20}$ This is a rough proxy of total holdings of mortgaged backed securities since this variable is only based on recognised mortgage backed securities. Banks might have other such securities held as collateral on repo and similar arrangements with counterparties and which are not recognised in the financial statements. Unless otherwise specified, these might be rehypothecated in other repo agreements. Information about such collateral is not publicly available.
} 
deposits as our proxy for long term stable financing and test whether the relative amount of short term repo financing when compared to deposits increased post BAPCPA. For this analysis, we only keep those observations for banks that increased repurchase agreements postBAPCPA.

The results for this analysis are shown in Table 15 and the variable of interest is POST. The sign and statistical significance of the coefficient on POST indicates whether the dependent variable has increased post BAPCPA. In model (1) of Table 15 we test whether the banks which increased the amount of repo agreements post BAPCPA also increased their deposits, where the variable DEPOSITS is calculated as total deposits scaled by total assets. In model (2) we test whether the relative amount of deposits to the sum of repo agreements and deposits has changed post-BAPCPA. To undertake the latter analysis, we construct a new variable DEPOSITS_REPO which is calculated as total deposits scaled by the sum of repo agreements and total deposits. Ex-ante we expect a statistically significant negative coefficient on POST for model (2) suggesting that the relative amount of deposits to repo agreements has decreased post-BAPCPA. Such a result would buttress our story that post-BAPCPA there was a shift from stable long-term financing to short term repo financing. All controls used in this analysis are as previously defined.

$<<$ Insert Table 15 around here>>

As shown in Table 15 model (1), POST is positive and statistically significant suggesting that banks that increased repo agreements post-BAPCPA, also increased their deposits. More importantly in model (2), POST is negative and statistically significant at the $1 \%$ level of significance suggesting that the relative amount of deposits to the sum of deposits and repo agreements has decreased post-BAPCPA. Specifically, this result indicates that the rate of increase in repo financing was higher than the rate of increase in deposit financing post- 
BAPCPA. This result vindicates our story that there was a shift from long term deposit financing to short term repo financing.

\section{Conclusion}

The Bankruptcy Abuse Prevention and Consumer Protection Act (BAPCPA) of 2005 brought about significant changes to the US Bankruptcy Code. While some of these changes related to personal bankruptcy law, changes were also made to business bankruptcy law. Particularly, the BAPCPA extended the so-called 'safe harbor' provisions, which exempt repo agreements from the normal workings of the Bankruptcy Code to repo agreements collateralized by riskier collateral. In this regard, while prior to the BAPCPA repo agreements availing of the 'safe harbor' provisions had to be collateralized by US government backed securities, following the BAPCPA repo agreements collateralized by riskier collateral such as mortgage backed securities were eligible for 'safe harbor' provisions.

While extending the preferential treatment afforded to repo agreements facilitates funding arrangements through this market, thus potentially reducing finance costs (finance cost factor), it potentially results in a substitution effect where stable long-term financing is substituted with runnable short-term financing (finance risk factor). While both factors were evident following the passage of the BAPCPA which factor dominates is an empirical question.

To address this research question, we identify major congressional events related to the passage of the BACPCPA and calculate abnormal market reactions in the three-day event windows around these events. Results indicate that the perceived finance risk arising from this change offsets the effect of any reduction in finance costs. Moreover, subsequent crosssectional analysis indicates that such market reaction is at least partly driven by repo exposure. 
Further, the undertaking of riskier repurchase transactions likely resulted in increased information asymmetry post-BAPCPA. Using a difference-in-differences approach, and measuring information asymmetry using the bid-ask spread, we find that firms which were exposed to repo agreements experienced increased information asymmetry following BAPCPA. Although the use of a difference-in-differences approach helps in mitigating endogeneity concerns, we acknowledge that our analysis lacks an ideal control group that would be made of US banks that are outside the scope of the BAPCPA.

Finally, further linking our results to the BAPCPA, we find that information asymmetry among market participants increased for firms with repo agreements and above average mortgage backed securities post BAPCPA. This result is particularly interesting since repo agreements collateralized with mortgage backed securities were the major type of repo agreements for which 'safe harbor' provisions were extended.

The unintended consequence of BAPCPA documented in this study is primarily driven by asynchronous changes in the bank regulatory framework. Specifically, in this case, it is the result of changes in bankruptcy legislation which are not accompanied by changes in accounting regulations requiring enhanced disclosures. This finding has significant policy implications since it suggests that policy makers need to account for how different regulations interact with each other, when proposing regulatory changes. 


\section{Reference list}

Acharya, V.V., Cooley, T. F., Richardson, M. P., and Walter, I. 2010. Regulating Wall Street: The Dodd-Frank Act and the new architecture of global finance (Vol. 608). John Wiley \& Sons.

Adrian, T., Begalle, B., Copeland, A., and Martin, A. 2012. Repo and securities lending. In Systemic Risk and Macro Modeling. University of Chicago Press.

Akgiray, V. 1989. Conditional heteroscedasticity in time series of stock returns: Evidence and forecasts. Journal of Business 62 (1): 55-80.

Ali, A., Durtschi, C., Lev, B., and Trombley, M. 2004. Changes in institutional ownership and subsequent earnings announcement abnormal returns. Journal of Accounting, Auditing and Finance 19: 221-248

Armstrong, S.C., Barth, E. M., Jagolinzer, D. A., and Riedl J. E. 2010. Market reaction to the adoption of IFRS in Europe. The Accounting Review 85 (1): 31-61

Ayotte, K. and Skeel, D. A. 2013. Bankruptcy Law as a Liquidity Provider. University of Chicago Law Review 80: 1557-1624.

Baklanova, V., Copeland, A. and McCaughrin, R. 2015. Reference guide to U.S. repo and securities lending markets. Federal Reserve Bank of New York Staff Reports, Staff Report No. 740.

Bankruptcy Abuse Prevention and Consumer Protection Act of 2005 S. $256\left(109^{\text {th }}\right)$.

Bankruptcy Amendments and Federal Judgeship Act of 1984 H.R. $5174\left(98^{\text {th }}\right)$.

Bankruptcy Reform Act of 2000 H.R. $833\left(106^{\text {th }}\right)$.

Beatty, A., Chamberlain, S. and Magliolo, J. 1996. An empirical analysis of economic implications of fair value accounting for investment securities. Journal of Accounting and Economics 22 (1-3): 43-77.

Beaver, W. 1998. Financial reporting: an accounting revolution ( $_{s} 3^{\text {rd }}$ ed), Prentice-Hall, Englewood Cliffs, NJ.

Benton, K.J. 2005. Banks and the 2005 Bankruptcy Abuse Prevention and Consumer Protection Act. Federal Reserve Bank of Philadelphia Compliance Corner: Fourth Quarter 2005 [online] Available at: https://www.philadelphiafed.org/bankresources/publications/compliance-corner/2005/fourth-quarter/q4cc1_05.

Bernard, L.V. 1987. Cross-sectional dependence and problems in inference in market-based accounting research. Journal of Accounting Research 25 (1): 1-48.

Binder, J.J. 1998. The event study methodology since 1969. Review of Quantitative Finance and Accounting 11: 111-137.

Bliss, R.R. and Kaufman, G.G. 2006. Derivatives and systemic risk: Netting, collateral and closeout. Journal of Financial Stability 2 (1): 55-70. 
Boehmer, E., Musumeci, J. and Poulsen, B.A. 1991, Event-study methodology under conditions of event-induced variance, Journal of Financial Economics 30: 253-272.

Bolton, P. And Oehmke, M. 2015. Should derivatives be privileged in bankruptcy? The Journal of Finance 70(6): 2353-2394.

Bushee, J.B. and Goodman, H.T. 2007. Which institutional investors trade based on private information about earnings and returns? Journal of Accounting Research 45(2): 289-321

Brown, S.J and Warner, J.B. 1980. Measuring security price performance. Journal of Financial Economics 8: 205-258.

Brown, S.J and Warner, J.B. 1985. Using daily returns: The case of event studies. Journal of Financial Economics 14, 3-31.

Brown, S.J and Weinstein, M.I. 1985. Derived factors in event studies. Journal of Financial Economics. 14: 491-495.

Cerbioni, F., Fabrizi, M., and Parbonetti, A. 2015. Securitizations and the financial crisis: Is accounting the missing link? Accounting Forum 39 (3): 155-175

Chircop, J. and Novotny-Farkas, Z. 2016. The economic consequences of extending the use of fiar value accounting in regulatory capital calculations. Journal of Accounting and Economics 62 (2-3): 183-203

Chircop, J., Kiosse, P.V., and Peasnell, K. 2012. Should repurchase transactions be accounted for as sales or loans? Accounting Horizons 26 (4): 657-679.

Dang, T.V., Gorton, G., and Holmstrom, B. 2011. Repo, haircuts and liquity [online] Available at: http://www.sef.hku.hk/conference11/Tri\%20Vi\%20DANG.pdf.

Dechow, P.M., Hutton, A.P., and Sloan, R.G. 1996. Economic consequences of accounting for stock-based compensation. Journal of Accounting Research 34: 1-20

Dickerson, M.A. 2006. Regulating bankruptcy: Public choice, ideology, \& beyond. Washington University Law Review 84 (7): 1861-1905.

Duffie, D. 1996. Special repo rates. The Journal of Finance 51 (2): 493-526.

Duffie, D., and Skeel, D. A. Jr. 2012. A dialogue on the costs and benefits of automatic stays for derivatives and repurchase agreements. University of Pennsylvania Law School Faculty Scholarship. $\quad 386 . \quad$ Paper Avline] Available http://scholarship.law.upenn.edu/faculty_scholarship/386.

Dyckman, T., Philbrick, D. and Stephen, J. 1984. A comparison of event study methodologies using daily stock returns: A simulation approach. Jouranl of Accounting Research 22: 1-33.

Edwards, R.F. and Morrison, R.E. 2005. Derivatives and the Bankruptcy Code: Why the special treatment? Yale Journal on Regulation 22 (1): 92-121. 
Fabrizi, M., and Parbonetti, A. 2015. CEO risk incentives and the riskiness of securitisation transactions in the financial industry. International Journal of Banking, Accounting and Finance 6 (2): 122-150.

Froot, A.K. 1989. Consistent covariance matrix estimation with cross-sectional dependence and heteroskedasticity in financial data. Journal of Financial and Quantitative Analysis 24 (3): 333-355.

FASB. 2000. Accounting for Transfers and Servicing of Financial Assets and Extinguishments of Liabilities, Connecticut: FASB.

FASB. 2009. Statement of Financial Accounting Standards No. 166 Accounting for Transfers of Financial Assets an amendment of FASB Statement No. 140, Connecticut: FASB.

FASB. 2013. Transfers and Servicing (Topic 860): Effective Control for Transfrers with Forward Agreements to Repurchase Assets and Accounting for Repurchase Financings (Exposure Draft), Connecticut: FASB.

FASB. 2014. Accounting Standards Update No. 2014-11. Transfers and Servicing (Topic 860): Repurchase-to-Maturity Transactions, Repurchase Financings, and Disclosures, Connecticut: FASB.

Fleming, M. J., Hrung, W. B., and Keane, F. M. 2009. The term securities lending facility: origin, design, and effects. Current Issues in Economics and Finance 15 (2): 1-11.

Ganduri, R. 2017. Repo Regret? [online] Available at: https://papers.ssrn.com/sol3/papers.cfm?abstract_id=2795340.

Gorton, G. 2009. Information, liquidity, and the (ongoing) panic of 2007. National Bureau of Economic Research Working Paper Series, No. 14649. [online] Available at: http://www.nber.org/papers/w14649.

Gorton, G., and Metrick, A. 2010. Haircuts. Federal Reserve Bank of St. Louis Review 92(6): 507-519.

Gorton, G., Metrick, A., Shleifer, A., and Tarullo, D. K. 2010. Regulating the shadow banking system [with comments and discussion]. Brookings Papers on Economic Activity, 261-312.

Gorton, G. and Metrick, A. 2012. Securitized banking and the run on repo. Journal of Financial Economics 104 (3): 425-451.

Greenspan, A. 1998. Hedge Fund Operations:Hearing before the House Committee on Banking and Financial Services, 105th Cong. 23.

Healy, M.P. and Palepu, G.K. 2001. Information asymmetry, corporate disclosure and the capital markets: A review of the empirical disclosure literature. Journal of Accounting and Economics 31 (1-3): 405-440.

Hördahl, P., and King, M. R. 2008. Developments in repo markets during the financial turmoil. BIS Quarterly Review (December): 37-57.

Horton, J., Serafeim, G. and Serafeim, I. 2013. Does mandatory IFRS adoption improve the information environment? Contemporary Accounting Research 30 (1): 388-423. 
Infante, S. 2013. Repo collateral fire sales: the effects of exemption from automatic stay. FEDS Working Paper No. 2013-83. [online] Available at: http://ssrn.com/abstract=2357664

Jain, P., and Rezaee, Z. 2006. The Sarbanes-Oxley Act of 2002 and capital-market behavior: Early evidence. Contemporary Accounting Research 23 (Fall): 629-654.

Kolari, J. W., and Pynnönen, S. 2010. Event study testing with cross-sectional correlation of abnormal returns, Review of Financial Studies 23: 3996-4025.

Krishnamurthy, A. 2010. How debt markets have malfunctioned in the crisis. Journal of Economic Perspectives 24 (1): 3-28.

Krishnamurthy, S, Zhou, J. and Zhou, N. 2006. Auditor reputation, auditor independence, and the stock-market impact of Andersen's indictments on its client firms. Contemporary Accounting Research 23 (2): 465-490

Leftwich, R. 1980. Market failure fallacies and accounting information. Journal of Accounting and Economics, 2: 193-211.

Li, H., Pincus, M. and Rego, S.O. 2008. Market reaction to events surrounding the SarbanesOxley Act of 2002 and earnings management. The Journal of Law \&Economics 51: 111134.

Lubben, S. J. 2009. Derivatives and bankruptcy: The flawed case for special treatment, University of Pennsylvania Journal of Business Law12 (1): 61-78.

Maclachlan, F. 2014. Repurchase agreements and the law: how legislative changes fueled the housing bubble. Journal of Economic Issues, 48(2): 515-522

Morrison, E.R., Roe, M.J. and Sontchi, C.S. 2014. Rolling back the repo Safe Harbors. The Business Lawyer 69 (4): 1015-1047.

Noonan, L. 2017. Higher interest rates point to more bank profits. Financial Times. March 13, 2017. [online] Available at: https://www.ft.com/content/f84dbae4-e713-11e6-967bc88452263daf?mhq5j=e7.

Ong, K. T. ., and Yeung, E. Y. 2011. Repos \& securities lending: the accounting arbitrage and their role in the global financial crisis. Capital Markets Law Journal 6 (1): 92.

Patell, J. A., 1976, Corporate forecasts of earnings per share and stock price behavior:

Empirical test. Journal of Accounting Research 14: 246-276.

Pinnuck, M. 2005. What is the abnormal return performance of mutual funds due to private earnings information? Journal of Contemporary Accounting and Economics 1: 193-216

Riechmann, D. 2000. Clinton vetoes bankruptcy bill. Associated Press. December 19, 2000. [online] Available at: http://www.apnewsarchive.com/2000/Clinton-Vetoes-BankruptcyBill/id-b52e0f874e5e4682442bf2e2dea2009b.

Roe, M.J. 2011. The derivatives market's payment priorities as financial crisis accelerator. Stanford Law Review 63 (3): 539-590. 
Roe, M.J. and F. Tung. 2013. Breaking bankruptcy priority: How rent-seeking upends the creditors' bargain. Virginia Law Review 99: 1235-1290.

Schroeder, J. L. 2002. Repo Opera: How Criimi Mae Got Repos Backwards, A. Am. Bankr. $L J, 76: 565$.

Sefcik, S.E. and R. Thompson. 1986. An approach to statistical inference in cross-sectional models with security abnormal returns as dependent variable. Journal of Accounting Research 24 (2): 316-334.

Stigum, M. L. 1989. The repo and reverse markets. Irwin Professional Pub.

Watts R. and Zimmerman, J. 1986. Positive Accounting Theory, Prentice-Hall, Englewood Cliffs, NJ.

Zhang, I. 2007. Economic consequences of the Sarbanes-Oxley Act of 2002. Journal of Accounting and Economics 44: 74-115. 


\section{Figure 1}

Primary Dealers' Outstanding Repos July 6, 1994 to July 22, 2009

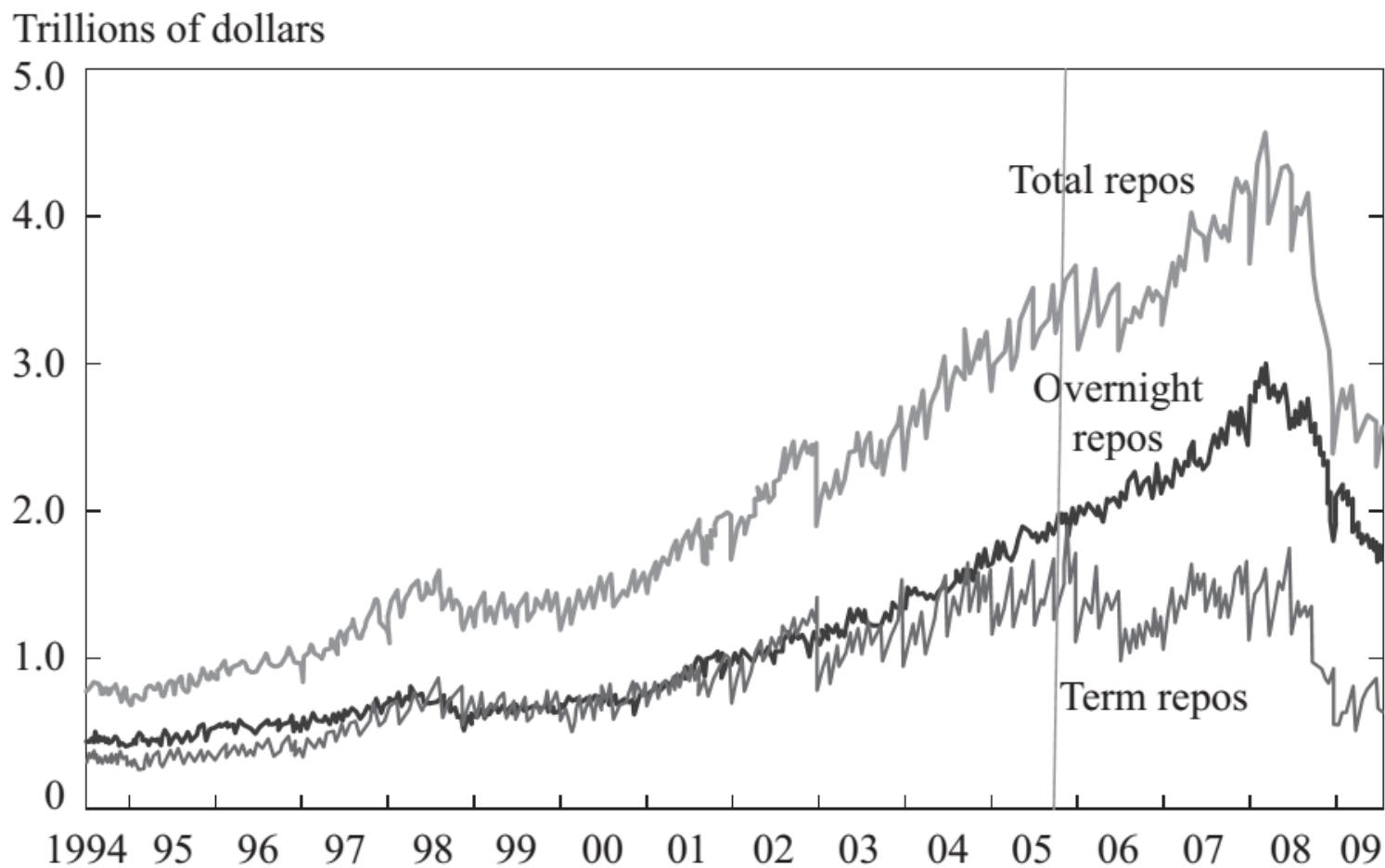

Figure 1: This figure shows the increase in repo agreements from July 6, 1994 to July 22, 2009. This figure is sourced from Adrian et al. (2009), Chart 1 in original, and a vertical line was added to show October 2005, the date the provisions of the BAPCPA became effective. 


\section{Figure 2}

\section{Overnight Repos as a Percentage of Total Primary Dealer Repo Financing January 5,}

2005 to July 22, 2009

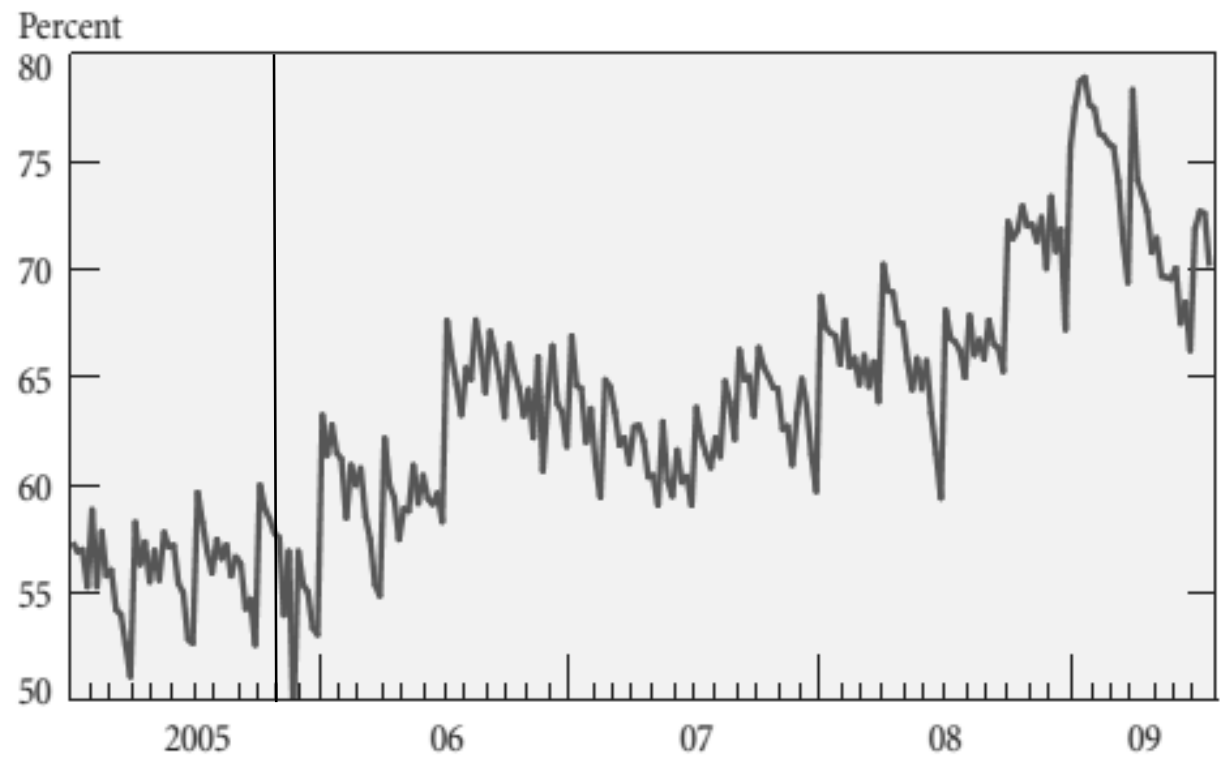

Figure 2: This figure shows the percentage of primary dealer overnight repo agreements as a percentage of total primary dealer repo agreements for the period January 5, 2005 to July 22, 2009. This figure is sourced from Adrian et al. (2009), Chart 2 in original, and a vertical line was added to show October 2005, the date the provisions of the BAPCPA became effective. 
Figure 3

Prevalance of Less Liquid Collateral in Primary Dealers' Repo Transactions January 5, 2005 - July 22, 2009

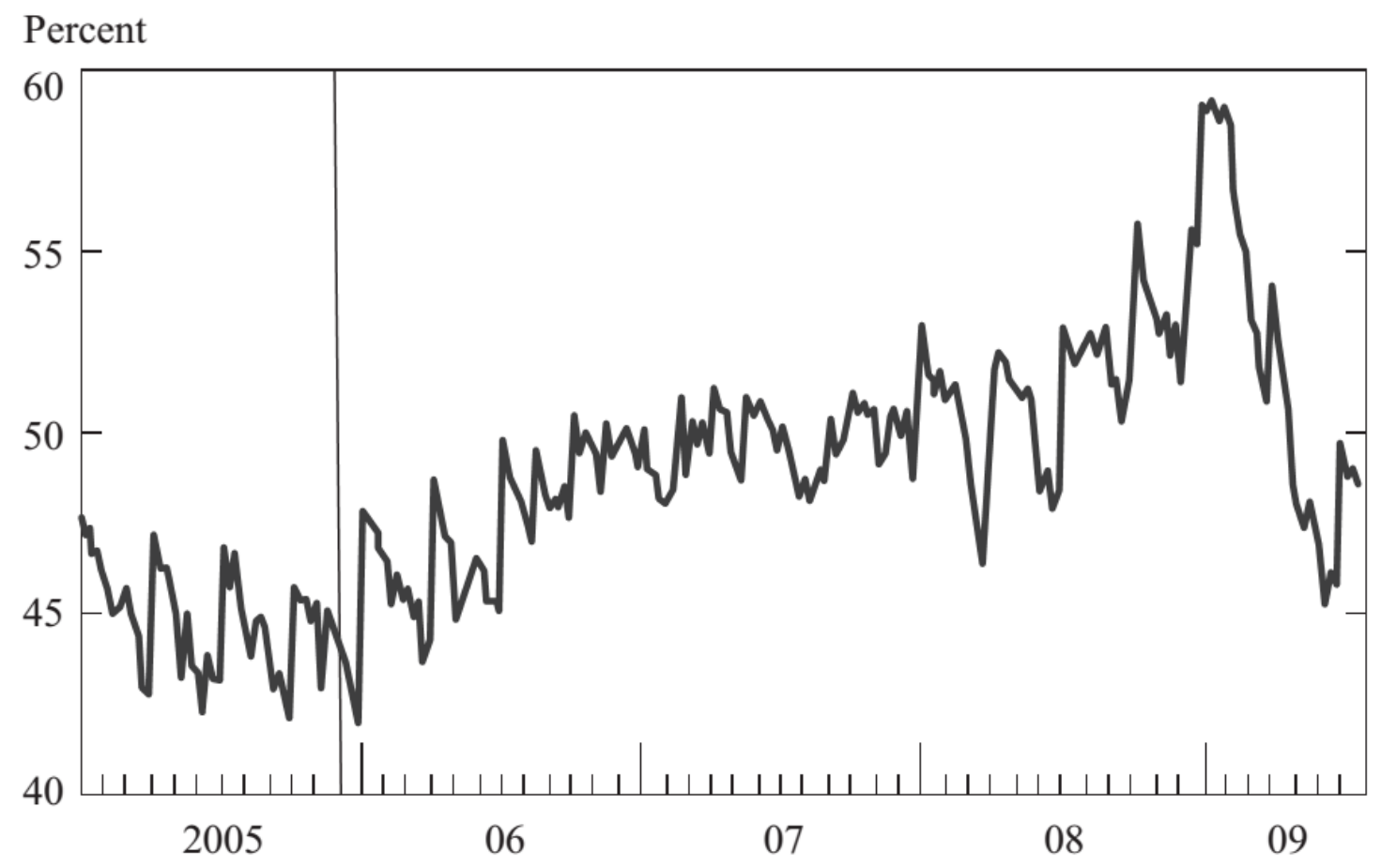

Figure 3: This figure shows the prevalence of less liquid collateral (e.g. corporate securities and mortgage backed securities) for the period January 5, 2005 to July 22, 2009. This figure is sourced from Adrian et al. (2009), Chart 3 in original, and a vertical line was added to show October 2005, the date the provisions of the BAPCPA became effective. 
Table 1

News events leading to the passage of the Bankruptcy Abuse Prevention and Consumer Protection Act of 2005

\begin{tabular}{ll}
\hline Date & Details of event \\
\hline & $\begin{array}{l}\text { Republican Senator Charles Grassley of Iowa (for himself together with seven original cosponsors) introduced S.256, the } \\
\text { 'Bankruptcy Abuse Prevention and Consumer Protection Act of 2005' in the Senate. } \\
\text { February 1, James Sensebrenner Jr., Chairman of the House Committee on the Judiciary (for himself together with 60 original } \\
\text { cosponsors) introduced legislation identical to S.256 in the House of Representatives (H.R. 685). }\end{array}$ \\
$\begin{array}{l}\text { February 9, 2005 } \\
\text { Parch 10, 2005 }\end{array}$ & $\begin{array}{l}\text { The House of Representatives passed the bill (S.256) with 302 votes in favour and 126 against (Roll No. 108). The Bill was } \\
\text { subsequently cleared for White House. }\end{array}$ \\
April 14, 2005 & Bill signed by President and became Public Law No: 109-008
\end{tabular}

Table 1: A list of major congressional events leading to the passage of the Bankruptcy Abuse Prevention and Consumer Protection Act of 2005. Events sourced from https://www.govtrack.us/congress/bills/109/s256. 
Table 2

\section{Distributional statistics for the variables used in Equation 1}

\begin{tabular}{lcccccc}
\hline \multicolumn{1}{c}{ Variable } & N & p25 & mean & p50 & p75 & sd \\
\hline & & & & & & \\
RET & 36818 & -0.010 & -0.001 & 0.000 & 0.007 & 0.016 \\
MKT_RET & 36818 & -0.006 & -0.001 & -0.001 & 0.003 & 0.007 \\
CHG_TREAS & 36818 & 0.000 & 0.000 & 0.000 & 0.000 & 0.000
\end{tabular}

Table 2: Distributional statistics for the variables used in Eq. $1 . R E T$ is the daily stock price return; $M K T \_R E T$ is the CRSP equally-weighted daily return; $C H G \_T R E A S$ is the daily change in the Barclays US treasury index and EVENT_ALL is an indicator variable that assumes a value of 1 on the day preceding, the day of, and the day after the event dates listed in Table 1 (where days are defined as CRSP trading days). The sample period runs from January 1, 2005 to April $30,2005$. 
Table 3

Pearson correlation for variables used in Equation 1

\begin{tabular}{lllll}
\hline \multicolumn{1}{r}{ Variable } & \multicolumn{1}{c}{ RET } & MKT_RET & CHG_TRES & EVENT_ALL \\
\hline & & & & \\
RET & 1.000 & & & \\
MKT_RET & $0.293^{* * *}$ & 1.000 & & \\
CHG_TREAS & $0.022^{* * *}$ & $0.099^{* * *}$ & 1.000 & \\
EVENT_ALL & $-0.016^{* *}$ & $-0.021^{* * *}$ & $0.056^{* * *}$ & 1.000
\end{tabular}

Table 3: Pearson correlation matrix for the variables used in Eq. $1 . R E T$ is the daily stock price return; $M K T \_R E T$ is the CRSP equally-weighted daily return; $C H G \_T R E A S$ is the daily change in the Barclays US treasury index and EVENT_ALL is an indicator variable that assumes a value of 1 on the day preceding, the day of, and the day after the event dates listed in Table 1 (where days are defined as CRSP trading days). The sample period runs from January 1, 2005 to April 30, $2005 . *, * *$ and *** denote significance at the $5 \%, 1 \%$ and $0.1 \%$ level of significance respectively. 


\section{Table 4}

\section{Multivariate regression analyzing market reactions to news events leading to the passage of the Bankruptcy Abuse Prevention and Consumer Protection Act of 2005.}

\begin{tabular}{lll}
\hline Variable & \multicolumn{1}{c}{ (1) } & \multicolumn{1}{c}{ RET } \\
\hline & & \\
MKT_RET & $0.7079^{* * *}$ & $0.7079^{* * * *}$ \\
& {$[22.373]$} & {$[22.373]$} \\
CHG_TREAS & -0.2664 & -0.2664 \\
& {$[-1.414]$} & {$[-1.414]$} \\
EVENT_ALL & $-0.0004^{* *}$ & 0.0005 \\
& {$[-2.375]$} & {$[1.597]$} \\
EVENT_ALL* REPO & & $-0.0014 * * *$ \\
& & {$[-3.525]$} \\
REPO & & -0.0000 \\
& & {$[-0.318]$} \\
Constant & $-0.0001^{*}$ & -0.0001 \\
& {$[-1.680]$} & {$[-0.669]$} \\
(EVENT_ALL + EVENT_ALL *REPO) $=0$ & & \\
& & F-test: 18.81 \\
& & p-value $<0.01$ \\
\hline Observations & & \\
No. of Banks & 36,818 & 36,818 \\
R-squared & 449 & 449 \\
\hline
\end{tabular}

Table 4: Regression (1) shows the results when running Equation 1 while regression (2) shows the results when Equation 1 is adjusted so as to include an interaction term between EVENT_ALL and REPO. RET is daily stock price return for firm $i, M K T \_R E T$ is CRSP equally-weighted daily return, $C H G_{-} T R E A S$ is the daily change in the Barclays US treasury index, and EVENT_ALL is an indicator variable that assumes a value of 1 on the day preceding, the day of, and the day after the event dates listed in Table 1 (where days are defined as CRSP trading days). $R E P O$ is an indicator variable that takes the value of 1 if the bank entered in repo agreements during the sample period, 0 otherwise. The sample period runs from January 1, 2005 to April 30, 2005. *,** and *** denote significance at the $10 \%, 5 \%$ and $1 \%$ level of significance respectively. Robust t-statistics shown in brackets. 
Table 5

Distributional statistics of the variables used in the cross-sectional analysis

\begin{tabular}{lcccccc}
\hline Variable & N & p25 & mean & p50 & p75 & sd \\
\hline REPO & & & & & & \\
REV_REPO & 449 & 0.000 & 0.686 & 1.000 & 1.000 & 0.465 \\
MKT_VAL & 449 & 0.000 & 0.116 & 0.000 & 0.000 & 0.320 \\
DERIV & 449 & 11.379 & 12.622 & 12.212 & 13.446 & 1.684 \\
LOANS_REAL & 449 & 0.000 & 0.123 & 0.000 & 0.028 & 0.575 \\
LOANS_DEP & 449 & 0.409 & 0.496 & 0.507 & 0.600 & 0.149 \\
LOANS_AGRIC & 449 & 0.000 & 0.000 & 0.000 & 0.000 & 0.001 \\
LOANS_COMM & 449 & 0.000 & 0.005 & 0.000 & 0.004 & 0.011 \\
LOANS_IND & 449 & 0.056 & 0.101 & 0.089 & 0.135 & 0.064 \\
LOANS_FOREIGN & 449 & 0.010 & 0.042 & 0.026 & 0.059 & 0.045 \\
SI & 449 & 0.000 & 0.000 & 0.000 & 0.000 & 0.000 \\
NI & 449 & 0.000 & 0.000 & 0.000 & 0.000 & 0.000 \\
CAPITAL_RATIO & 449 & 0.002 & 0.003 & 0.003 & 0.003 & 0.001 \\
\end{tabular}

Table 5: Distributional statistics for the variables used in the cross-sectional analysis. REPO is an indicator variable that takes the value of 1 if the bank entered in repo agreements during the sample period, 0 otherwise. $R E V \_R E P O$ is an indicator variable that takes the value of 1 if the bank entered in reverse repo agreements during the sample period, 0 otherwise. $M K T_{-} V A L$ is the logarithm of market capitalization; DERIV is the amount of derivatives; $L O A N S \_R E A L$ is the amount of loans secured by real estate; LOANS DEP is the amount of loans to depository institutions; LOANS AGRIC is the amount of loans to finance agricultural production; LOANS COMM is the amount of commercial and industrial loans; LOANS_IND is the amount of loans to individuals; LOANS_FOREIGN is the amount of loans to foreign governments; SI is securitization income; NI is net income; CAPITAL_RATIO is the bank's capital ratio. All continuous variables with the exception of $M K T \_V A L$ and $C A P I T A L \_R A T I O$ are standardized by total assets and winsorized at the $1^{\text {st }}$ and $99^{\text {th }}$ percentile. All continuous variables are calculated as the mean values for the quarters ending December 31 , 2014 and March 31 , 2015 . 
Table 6

Pearson correlation matrix of the variables used in the cross-sectional analysis

\begin{tabular}{|c|c|c|c|c|c|c|c|c|c|c|c|c|}
\hline Variable & REPO & REV_REPO & MKT_VAL & DERIV & $\begin{array}{c}\text { LOANS_ } \\
\text { REAL }\end{array}$ & $\begin{array}{c}\text { LOANS } \\
\text { DEP }\end{array}$ & $\begin{array}{c}\text { LOANS } \\
\text { AGRIC }\end{array}$ & $\begin{array}{c}\text { LOANS } \\
\text { COMM }\end{array}$ & $\begin{array}{c}\text { LOANS } \\
\text { IND }\end{array}$ & $\begin{array}{l}\text { LOANS }_{-} \\
\text {FOREIGN }\end{array}$ & SI & NI \\
\hline REPO & 1.000 & & & & & & & & & & & \\
\hline REV_REPO & $0.140 * *$ & 1.000 & & & & & & & & & & \\
\hline MKT_VAL & $0.273 * * *$ & $0.529 * * *$ & 1.000 & & & & & & & & & \\
\hline DERIV & $0.113^{*}$ & $0.464 * * *$ & $0.503 * * *$ & 1.000 & & & & & & & & \\
\hline LOANS_REAL & $-0.168 * * *$ & $-0.274 * * *$ & $-0.422 * * *$ & $-0.300 * * *$ & 1.000 & & & & & & & \\
\hline LOANS_DEP & 0.058 & $0.226 * * *$ & $0.248 * * *$ & $0.283 * * *$ & -0.045 & 1.000 & & & & & & \\
\hline LOANS_AGRIC & -0.042 & -0.085 & -0.088 & -0.072 & -0.081 & -0.027 & 1.000 & & & & & \\
\hline LOANS_COMM & 0.048 & 0.039 & 0.079 & -0.061 & $-0.148 * *$ & 0.090 & $0.144 * *$ & 1.000 & & & & \\
\hline LOANS_IND & $0.128 * *$ & 0.03 & $0.211^{* * *}$ & 0.071 & $-0.301 * * *$ & 0.005 & 0.03 & 0.019 & 1 & & & \\
\hline LOANS_FOREIGN & 0.07 & $0.267 * * *$ & $0.295^{* * *}$ & $0.437 * * *$ & $-0.148 * *$ & $0.218 * * *$ & -0.061 & 0 & 0.082 & 1 & & \\
\hline SI & 0.01 & $0.255 * * *$ & $0.341 * * *$ & $0.482 * * *$ & $-0.209 * * *$ & $0.100 *$ & -0.053 & -0.065 & $0.189 * * *$ & $0.269 * * *$ & 1 & \\
\hline $\mathrm{NI}$ & 0.033 & $0.158 * * *$ & $0.433 * * *$ & $0.113^{*}$ & $-0.112 *$ & 0.069 & 0.000 & 0.085 & 0.082 & -0.022 & $0.099 *$ & 1 \\
\hline CAPITAL_RATIO & $-0.142 * *$ & -0.016 & $-0.110^{*}$ & -0.054 & $-0.344 * * *$ & -0.057 & -0.067 & $-0.287 * * *$ & -0.035 & -0.054 & 0.056 & -0.034 \\
\hline
\end{tabular}

Table 6: Pearson correlation matrix for the variables used in model (2). REPO is an indicator variable that takes the value of 1 if the bank entered in repo agreements during the sample period, 0 otherwise. $R E V \_R E P O$ is an indicator variable that takes the value of 1 if the bank entered in reverse repo agreements during the sample period, 0 otherwise. $M K T \_V A L$ is the logarithm of market capitalization; DERIV is the amount of derivatives; LOANS_REAL is the amount of loans secured by real estate; LOANS_DEP is the amount of loans to depository institutions; $L O A N S$ AGRIC is the amount of loans to finance agricultural production; $L O A N S$ COMM is the amount of commercial and industrial loans; LOANS_IND is the amount of loans to individuals; LOANS_FOREIGN is the amount of loans to foreign governments; SI is securitization income; NI is net income; CAPITAL_RATIO is the bank's capital ratio. All continuous variables with the exception of MKT_VAL and CAPITAL_RATIO are standardized by total assets and winsorized at the $1^{\text {st }}$ and $99^{\text {th }}$ percentile. All continuous variables are calculated as the mean values for the quarters ending December 31,2014 and March 31 , 2015.*, ** and $* * *$ denote significance at the $5 \%, 1 \%$ and $0.1 \%$ level of significance respectively. 
Table 7

\section{Cross-sectional analyses}

Panel A: 2- Stage Regression

\begin{tabular}{|c|c|}
\hline Variable & BETA \\
\hline REPO & $\begin{array}{l}-0.0008 * * \\
{[-2.173]}\end{array}$ \\
\hline REV_REPO & $\begin{array}{l}0.0013 * \\
{[1.960]}\end{array}$ \\
\hline MKT_VAL & $\begin{array}{l}-0.0007 * * * \\
{[-4.768]}\end{array}$ \\
\hline DERIV & $\begin{array}{l}0.0008 * * \\
{[2.074]}\end{array}$ \\
\hline LOANS_REAL & $\begin{array}{l}0.0005 \\
{[0.326]}\end{array}$ \\
\hline LOANS_DEP & $\begin{array}{l}-0.0053 \\
{[-0.036]}\end{array}$ \\
\hline LOANS_AGRIC & $\begin{array}{l}-0.0116 \\
{[-0.763]}\end{array}$ \\
\hline LOANS_COMM & $\begin{array}{l}0.0032 \\
{[1.114]}\end{array}$ \\
\hline LOANS_IND & $\begin{array}{l}0.0003 \\
{[0.063]}\end{array}$ \\
\hline LOANS_FOREIGN & $\begin{array}{l}-0.7987 \\
{[-0.467]}\end{array}$ \\
\hline SI & $\begin{array}{l}-3.0764 \\
{[-1.630]}\end{array}$ \\
\hline NI & $\begin{array}{l}0.2114 \\
{[1.377]}\end{array}$ \\
\hline CAPITAL_RATIO & $\begin{array}{l}-0.0000 \\
{[-0.219]}\end{array}$ \\
\hline Constant & $\begin{array}{l}0.0084 * * * \\
{[3.042]}\end{array}$ \\
\hline Observations & 449 \\
\hline R-squared & 0.104 \\
\hline
\end{tabular}

Panel B: Sefcik and Thompson Adjustment

\begin{tabular}{ll}
\hline Variable & \multicolumn{1}{c}{ Adj_RET } \\
\hline \multirow{2}{*}{ REPO } & $-0.0008^{*}$ \\
& {$[-1.776]$} \\
REV_REPO & 0.0013 \\
& {$[1.565]$} \\
MKT_VAL & -0.0007 \\
& {$[-1.580]$} \\
DERIV & $0.0008^{*}$ \\
& {$[1.683]$} \\
LOANS_REAL & 0.0005 \\
& {$[0.265]$} \\
LOANS_DEP & -0.0053 \\
& {$[-0.028]$} \\
LOANS_AGRIC & -0.0116 \\
& {$[-0.615]$} \\
LOANS_COMM & 0.0032 \\
& {$[1.005]$} \\
LOANS_IND & 0.0003 \\
& {$[0.052]$} \\
LOANS_FOREIGN & -0.7987 \\
SI & {$[-0.553]$} \\
NI & -3.0764 \\
CAPITAL_RATIO & {$[-1.542]$} \\
Constant & 0.2114 \\
& {$[1.245]$} \\
Observations & -0.0000 \\
& {$[-0.182]$} \\
& 0.0084 \\
& {$[1.429]$} \\
& \\
& \\
& \\
&
\end{tabular}

Table 7: Results for the cross-sectional analyses. Panel A, shows the results of the two-stage regression, while Panel B shows the results of the Sefcik and Thompson (1986) which controls for heteroscedasticity and residual cross-correlation. In Panel A we have one observation for each bank (449 banks), while due to the methodological requirements of the Sefcik and Thompson (1986) adjustment in Panel B we have one observation for each trading day in our sample period ( 82 days). REPO is an indicator variable that takes the value of 1 if the bank entered in repo agreements during the sample period, 0 otherwise. $R E V \_R E P O$ is an indicator variable that takes the value of 1 if the bank entered in reverse repo agreements during the sample period, 0 otherwise. $M K T_{-} V A L$ is the logarithm of market capitalization; DERIV is the amount of derivatives; LOANS_REAL is the amount of loans secured by real estate; LOANS_DEP is the amount of loans to depository institutions; LOANS_AGRIC is the amount of loans to finance agricultural production; LOANS_COMM is the amount of commercial and industrial loans; LOANS_IND is the amount of loans 
to individuals; LOANS_FOREIGN is the amount of loans to foreign governments; SI is securitization income; NI is net income; CAPITAL_RATIO is the bank's capital ratio. All continuous variables with the exception of $M K T \_V A L$ and CAPITAL_RATIO are standardized by total assets and winsorized at the $1^{\text {st }}$ and $99^{\text {th }}$ percentile. All continuous variables are calculated as the mean values for the quarters ending December 31, 2014 and March 31, 2015. *,** and $* * *$ denote significance at the $10 \%, 5 \%$ and $1 \%$ level of significance respectively. Robust t-statistics shown in brackets. 
Table 8

Additional tests to address the inferential problems arising from event date clustering

\begin{tabular}{rrccc}
\hline & & & $\begin{array}{c}\text { Boehmer, } \\
\text { Patell } \\
\text { Musumeci } \\
\text { (1976) } \\
\text { \& Poulsen } \\
(\mathbf{1 9 9 1 )}\end{array}$ & $\begin{array}{c}\text { Kolari \& } \\
\text { Pynnönen } \\
(\mathbf{2 0 1 0})\end{array}$ \\
\hline-1 & -0.0012 & $* * *$ & $* *$ & \\
0 & -0.0111 & $* * *$ & $* * *$ & $* *$ \\
+1 & 0.0012 & & & \\
\hline
\end{tabular}

Table 8: Results for the robustness tests on the event study. RET is the daily average return for sample banks on the day prior to the event $(-1)$, the day of the event $(0)$, and the day after the event $(+1)$. * ** and *** denote significance at the $10 \%, 5 \%$ and $1 \%$ level of significance respectively. 
Table 9

Distributional statistics of variables used in Equation 3

\begin{tabular}{|c|c|c|c|c|c|c|}
\hline Variable & $\mathbf{N}$ & p25 & mean & p50 & p75 & sd \\
\hline SPR & 1217 & 0.001 & 0.002 & 0.002 & 0.003 & 0.003 \\
\hline MKT_VAL & 1217 & 12.892 & 14.052 & 13.787 & 14.913 & 1.606 \\
\hline DERIV & 1217 & 0.000 & 0.288 & 0.018 & 0.112 & 0.850 \\
\hline LOANS_REAL & 1217 & 0.366 & 0.441 & 0.458 & 0.532 & 0.143 \\
\hline LOANS_DEP & 1217 & 0.000 & 0.001 & 0.000 & 0.000 & 0.002 \\
\hline LOANS_AGRIC & 1217 & 0.000 & 0.005 & 0.001 & 0.006 & 0.010 \\
\hline LOANS_COMM & 1217 & 0.067 & 0.116 & 0.105 & 0.153 & 0.070 \\
\hline LOANS_IND & 1217 & 0.015 & 0.051 & 0.038 & 0.079 & 0.044 \\
\hline LOANS_FOREIGN & 1217 & 0.000 & 0.000 & 0.000 & 0.000 & 0.000 \\
\hline SI & 1217 & 0.000 & 0.000 & 0.000 & 0.000 & 0.000 \\
\hline NI & 1217 & 0.003 & 0.007 & 0.006 & 0.010 & 0.004 \\
\hline CAPITAL_RATIO & 1217 & 11.610 & 13.108 & 12.510 & 13.980 & 2.323 \\
\hline REV_REPO & 1217 & 0.000 & 0.005 & 0.000 & 0.000 & 0.019 \\
\hline
\end{tabular}

\begin{tabular}{|c|c|c|c|c|c|c|}
\hline Variable & $\mathbf{N}$ & p25 & mean & p50 & p75 & sd \\
\hline SPR & 1920 & 0.003 & 0.010 & 0.007 & 0.015 & 0.009 \\
\hline MKT_VAL & 1920 & 11.426 & 12.196 & 11.934 & 12.718 & 1.140 \\
\hline DERIV & 1920 & 0.000 & 0.066 & 0.000 & 0.013 & 0.412 \\
\hline LOANS_REAL & 1920 & 0.426 & 0.528 & 0.533 & 0.631 & 0.142 \\
\hline LOANS_DEP & 1920 & 0.000 & 0.000 & 0.000 & 0.000 & 0.002 \\
\hline LOANS_AGRIC & 1920 & 0.000 & 0.006 & 0.000 & 0.005 & 0.013 \\
\hline LOANS_COMM & 1920 & 0.056 & 0.098 & 0.086 & 0.127 & 0.060 \\
\hline LOANS_IND & 1920 & 0.011 & 0.037 & 0.024 & 0.048 & 0.039 \\
\hline LOANS_FOREIGN & 1920 & 0.000 & 0.000 & 0.000 & 0.000 & 0.000 \\
\hline SI & 1920 & 0.000 & 0.000 & 0.000 & 0.000 & 0.000 \\
\hline NI & 1920 & 0.003 & 0.006 & 0.005 & 0.008 & 0.004 \\
\hline CAPITAL_RATIO & 1920 & 11.680 & 13.895 & 12.915 & 14.860 & 3.596 \\
\hline REV_REPO & 1920 & 0.000 & 0.002 & 0.000 & 0.000 & 0.011 \\
\hline
\end{tabular}

Table 9: Distributional statistics for the variables used in Equation 3 for treated (Panel A) and control (Panel B) groups. $S P R$ is the average bid-ask spread standardized by the average stock price; $M K T_{-} V A L$ is the logarithm of market capitalization; DERIV is the amount of derivatives ; LOANS_REAL is the amount of loans secured by real estate; LOANS_DEP is the amount of loans to depository institutions; LOANS_AGRIC is the amount of loans to finance agricultural production; LOANS_COMM is the amount of commercial and industrial loans; LOANS_IND is the amount of loans to individuals; LOANS_FOREIGN is the amount of loans to foreign governments; SI is securitization income; NI is net income; CAPITAL_RATIO is the bank's capital ratio; REV_REPO is the amount of reverse repo agreements. All continuous variables with the exception of MKT_VAL and CAPITAL_RATIO are scaled by total assets. Variables are winsorized at the $1^{\text {st }}$ and $99^{\text {th }}$ percentile. All variables are calculated quarterly for the five quarters 2004Q1 to 2005Q1 representing the period pre BAPCPA and the five quarters 2005Q4 to $2006 \mathrm{Q} 4$ representing the period post BAPCPA. 
Table 10

Pearson correlation matrix of the variables used in Equation 3

\begin{tabular}{|c|c|c|c|c|c|c|c|c|c|c|c|c|}
\hline Variable & SPR & MKT_VAL & DERIV & $\begin{array}{c}\text { LOANS } \\
\text { REAL }\end{array}$ & $\begin{array}{c}\text { LOANS_ } \\
\text { DEP }\end{array}$ & $\begin{array}{c}\text { LOANS } \\
\text { AGRIC } \\
\end{array}$ & $\begin{array}{c}\text { LOANS } \\
\text { COMM }\end{array}$ & $\begin{array}{c}\text { LOANS_ } \\
\text { IND }\end{array}$ & SI & NI & $\begin{array}{c}\text { CAPITAL_ }_{-} \\
\text {RATIO }\end{array}$ & $\begin{array}{l}\text { REV }_{-} \\
\text {REPO }\end{array}$ \\
\hline SPR & 1 & & & & & & & & & & & \\
\hline MKT_VAL & $-0.667 * * *$ & 1 & & & & & & & & & & \\
\hline DERIV & $-0.177 * * *$ & $0.509 * * *$ & 1 & & & & & & & & & \\
\hline LOANS_REAL & $0.177 * * *$ & $-0.426 * * *$ & $-0.295^{* * *}$ & 1 & & & & & & & & \\
\hline LOANS_DEP & $-0.132 * * *$ & $0.226^{* * *}$ & $0.230^{* * *}$ & $-0.142 * * *$ & 1 & & & & & & & \\
\hline LOANS_AGRIC & $0.072 * * *$ & $-0.128 * * *$ & $-0.083^{* * *}$ & $-0.080 * * *$ & $-0.040^{*}$ & 1 & & & & & & \\
\hline LOANS_COMM & $-0.078 * * *$ & $0.083^{* * *}$ & $-0.067 * * *$ & $-0.193^{* * *}$ & $0.108 * * *$ & $0.118 * * *$ & 1 & & & & & \\
\hline LOANS_IND & $-0.078 * * *$ & $0.164 * * *$ & 0.028 & $-0.231 * * *$ & 0.017 & 0.034 & 0.004 & 1 & & & & \\
\hline LOANS_FOREIGN & $-0.114 * * *$ & $0.307 * * *$ & $0.407 * * *$ & $-0.143^{* * *}$ & $0.153 * * *$ & $-0.049 * *$ & 0.014 & $0.055^{* *}$ & 1 & & & \\
\hline SI & $-0.119 * * *$ & $0.287 * * *$ & $0.396 * * *$ & $-0.062 * * *$ & $0.082 * * *$ & $-0.052 * *$ & -0.026 & 0.007 & $0.173 * * *$ & 1 & & \\
\hline $\mathrm{NI}$ & $-0.290 * * *$ & $0.356^{* * *}$ & $0.106^{* * *}$ & $-0.063 * * *$ & $0.066^{* * *}$ & -0.011 & 0.03 & $0.053^{* *}$ & $0.048^{* *}$ & $0.100 * * *$ & 1 & \\
\hline CAPITAL_RATIO & $0.073^{* * *}$ & $-0.068 * * *$ & -0.003 & $-0.309 * * *$ & -0.023 & $-0.079 * * *$ & $-0.279 * * *$ & $-0.082 * * *$ & $-0.076^{* * *}$ & $-0.037 *$ & 0.02 & 1 \\
\hline REV_REPO & $-0.128 * * *$ & $0.387 * * *$ & $0.647 * * *$ & $-0.266^{* * *}$ & $0.118 * * *$ & $-0.067 * * *$ & $-0.088 * * *$ & -0.002 & $0.272 * * *$ & $0.389 * * *$ & $0.054 * *$ & 0.011 \\
\hline
\end{tabular}

Table 10: Pearson correlation matrix for the variables used in Equation 3. All variables defined as in Table 9. *, ** and *** denote significance at the 5\%, $1 \%$ and $0.1 \%$ level of significance respectively. 


\section{Table 11}

\section{Effect of BAPCPA on information asymmetry: Parallel trend assumption}

\begin{tabular}{ll}
\cline { 2 - 2 } & \multicolumn{1}{c}{ SPR } \\
\hline Dummy_2004q1 * TREATED & $/ /$ \\
Dummy_2004q2* TREATED & 0.0001 \\
& {$[0.248]$} \\
Dummy_2004q3 * TREATED & 0.0001 \\
& {$[0.216]$} \\
Dummy_2004q4 * TREATED & 0.0007 \\
& {$[1.590]$} \\
Dummy_2005q1* TREATED & -0.0002 \\
& {$[-0.311]$} \\
& \\
& F-test: 1.75 \\
& p-value $>0.1$ \\
Main effects included & \\
All controls & YES \\
Bank Fixed Effects & YES \\
Observations & YES \\
\hline
\end{tabular}

Table 11: Results from testing the parallel trend assumption. *** and *** denote significance at the $10 \%, 5 \%$ and $1 \%$ level of significance respectively. Robust t-statistics shown in brackets. 
Table 12

Effect of BAPCPA on information asymmetry: Results from the diff-in-diff approach

\begin{tabular}{|c|c|}
\hline Variable & $\begin{array}{c}(1) \\
\text { SPR }\end{array}$ \\
\hline POST & $\begin{array}{l}-0.0029 * * * \\
{[-6.293]}\end{array}$ \\
\hline TREATED & $\begin{array}{l}-0.0011 \\
{[-0.376]}\end{array}$ \\
\hline POST*TREATED & $\begin{array}{l}0.0019 * * * \\
{[5.705]}\end{array}$ \\
\hline MKT_VAL & $\begin{array}{l}-0.0037 * * * \\
{[-5.499]}\end{array}$ \\
\hline DERIV & $\begin{array}{l}0.0002 \\
{[1.143]}\end{array}$ \\
\hline LOANS_REAL & $\begin{array}{l}-0.0041 \\
{[-1.032]}\end{array}$ \\
\hline LOANS_DEP & $\begin{array}{l}-0.0239 \\
{[-0.623]}\end{array}$ \\
\hline LOANS_AGRIC & $\begin{array}{l}-0.0072 \\
{[-0.220]}\end{array}$ \\
\hline LOANS_COMM & $\begin{array}{l}0.0102 * \\
{[1.777]}\end{array}$ \\
\hline LOANS_IND & $\begin{array}{l}0.0119 \\
{[0.891]}\end{array}$ \\
\hline LOANS_FOREIGN & $\begin{array}{l}-0.9937 \\
{[-1.231]}\end{array}$ \\
\hline SI & $\begin{array}{l}0.4731 \\
{[0.662]}\end{array}$ \\
\hline NI & $\begin{array}{l}0.0975 * * \\
{[1.992]}\end{array}$ \\
\hline CAPITAL_RATIO & $\begin{array}{l}-0.0002 * * \\
{[-2.471]}\end{array}$ \\
\hline REV_REPO & $\begin{array}{l}0.0051 \\
{[0.304]}\end{array}$ \\
\hline Constant & $\begin{array}{l}0.0691 * * * \\
{[5.586]}\end{array}$ \\
\hline Quarter Fixed Effects & YES \\
\hline Bank Fixed Effects & YES \\
\hline Observations & 3,137 \\
\hline R-squared & 0.871 \\
\hline
\end{tabular}

Table 12: Results for the information asymmetry models. All variables defined as in Table $9 . * * *$ and $* * *$ denote significance at the $10 \%, 5 \%$ and $1 \%$ level of significance respectively. Robust t-statistics shown in brackets. 
Table 13

Robustness tests

\begin{tabular}{|c|c|c|c|c|c|}
\hline \multirow[b]{2}{*}{ Variable } & $\begin{array}{c}(1) \\
\text { SPR }\end{array}$ & $\begin{array}{c}(2) \\
\text { SPR }\end{array}$ & $\begin{array}{c}(3) \\
\text { SPR }\end{array}$ & $\begin{array}{c}(4) \\
\text { SPR }\end{array}$ & $\begin{array}{c}(5) \\
\text { SPR }\end{array}$ \\
\hline & $\begin{array}{c}\text { Only } 4 \text { quarters } \\
\text { pre and post }\end{array}$ & $\begin{array}{c}\text { Only } 3 \text { quarters } \\
\text { pre and post }\end{array}$ & $\begin{array}{c}\text { Controlling for } \\
\text { size using total } \\
\text { assets }\end{array}$ & Using GLM & $\begin{array}{c}\text { Winsorization } \\
\text { at } 5 \%\end{array}$ \\
\hline \multirow[t]{2}{*}{ POST } & $-0.0031 * * *$ & $-0.0020 * * *$ & $-0.0018 * * *$ & $-0.0039 * * *$ & $-0.0024 * * *$ \\
\hline & {$[-6.470]$} & {$[-4.514]$} & {$[-4.412]$} & {$[-8.071]$} & {$[-6.931]$} \\
\hline \multirow[t]{2}{*}{ TREATED } & -0.0027 & $0.0088^{*}$ & $0.0029 * *$ & $0.0044 *$ & -0.0015 \\
\hline & {$[-0.472]$} & {$[1.792]$} & {$[2.060]$} & {$[1.664]$} & {$[-0.674]$} \\
\hline \multirow[t]{2}{*}{ POST*TREATED } & $0.0017 * * *$ & $0.0015 * * *$ & $0.0019 * * *$ & $0.0019 * * *$ & $0.0015 * * *$ \\
\hline & {$[5.270]$} & {$[4.408]$} & {$[5.481]$} & {$[6.102]$} & {$[5.363]$} \\
\hline \multirow[t]{2}{*}{ Constant } & $0.0610 * * *$ & $0.0404 * * *$ & $0.0747 * * *$ & $0.0577 * * *$ & $0.0668 * * *$ \\
\hline & {$[4.765]$} & {$[4.314]$} & {$[5.126]$} & [7.294] & {$[6.577]$} \\
\hline All Controls & YES & YES & YES & YES & YES \\
\hline Quarter Fixed Effects & YES & YES & YES & YES & YES \\
\hline Bank Fixed Effects & YES & YES & YES & YES & YES \\
\hline Observations & 2,557 & 1,886 & 3,173 & 3,137 & 3,137 \\
\hline R-squared & 0.877 & 0.893 & 0.862 & $/ /$ & 0.896 \\
\hline
\end{tabular}

Table 13: Robustness tests for results for the information asymmetry model. All variables defined as in Table 9. $*, * *$ and $* * *$ denote significance at the $10 \%, 5 \%$ and $1 \%$ level of significance respectively. Robust t-statistics shown in brackets. 
Table 14

Effect of increase in repo and high MBS on information asymmetry

\begin{tabular}{|c|c|}
\hline Variable & $\begin{array}{c}(1) \\
\text { SPR }\end{array}$ \\
\hline POST & $\begin{array}{l}-0.0027 * * * \\
{[-5.885]}\end{array}$ \\
\hline TREATED & $\begin{array}{l}-0.0112 * * \\
{[-2.505]}\end{array}$ \\
\hline POST*TREATED*HIGH_MBS & $\begin{array}{l}0.0007^{*} \\
{[1.839]}\end{array}$ \\
\hline POST*TREATED & $\begin{array}{l}0.0016^{* * *} \\
{[4.788]}\end{array}$ \\
\hline HIGH_MBS & $\begin{array}{l}0.0011^{* *} \\
{[2.920]}\end{array}$ \\
\hline POST*HIGH_MBS & $\begin{array}{l}-0.0000 \\
{[-0.104]}\end{array}$ \\
\hline TREATED*HIGH_MBS & $\begin{array}{l}-0.0015 * * * \\
{[-4.237]}\end{array}$ \\
\hline MKT_VAL & $\begin{array}{l}-0.0035 * * * \\
{[-6.107]}\end{array}$ \\
\hline DERIV & $\begin{array}{l}0.0001 \\
{[1.065]}\end{array}$ \\
\hline LOANS_REAL & $\begin{array}{l}-0.0113 * * * \\
{[-5.192]}\end{array}$ \\
\hline LOANS_DEP & $\begin{array}{l}-0.0080 \\
{[-0.226]}\end{array}$ \\
\hline LOANS_AGRIC & $\begin{array}{l}-0.0206 \\
{[-0.828]}\end{array}$ \\
\hline LOANS_COMM & $\begin{array}{l}0.0243 * * \\
{[2.462]}\end{array}$ \\
\hline LOANS_IND & $\begin{array}{l}0.0062 \\
{[0.742]}\end{array}$ \\
\hline LOANS_FOREIGN & $\begin{array}{l}-0.9162 \\
{[-1.780]}\end{array}$ \\
\hline SI & $\begin{array}{l}0.4340 \\
{[1.034]}\end{array}$ \\
\hline NI & $\begin{array}{l}0.0705 \\
{[0.937]}\end{array}$ \\
\hline CAPITAL_RATIO & $\begin{array}{l}-0.0002 * * * \\
{[-3.384]}\end{array}$ \\
\hline REV_REPO & $\begin{array}{l}0.0043 \\
{[0.238]}\end{array}$ \\
\hline Constant & $\begin{array}{l}0.0750 * * * \\
{[10.566]}\end{array}$ \\
\hline Quarter Fixed Effects & YES \\
\hline Bank Fixed Effects & YES \\
\hline Observations & 3,137 \\
\hline R-squared & 0.847 \\
\hline
\end{tabular}


Table 14: Results for the information asymmetry model when we control for mortgage backed securities (MBS) holdings. HIGH_MBS is an indicator variable that takes the value of 1 if the amortized cost of mortgage backed securities is above mean, 0 otherwise. All other variables defined as in Table $9 . * * *$ and $* * *$ denote significance at the $10 \%, 5 \%$ and $1 \%$ level of significance respectively. Robust t-statistics shown in brackets. 
Table 15

Repos vs Deposits in the Post-Period

\begin{tabular}{|c|c|c|}
\hline Variable & $\begin{array}{r}(1) \\
\text { DEPOSITS } \\
\end{array}$ & \begin{tabular}{l}
\multicolumn{1}{c}{$(2)$} \\
DEPOSITS vs \\
REPO \\
\end{tabular} \\
\hline POST & $\begin{array}{l}0.0078^{*} \\
{[2.067]}\end{array}$ & $\begin{array}{l}-0.0066 * * * \\
{[-3.915]}\end{array}$ \\
\hline MKT_VAL & $\begin{array}{l}-0.0331 * * * \\
{[-5.440]}\end{array}$ & $\begin{array}{l}-0.0149 * * * \\
{[-5.470]}\end{array}$ \\
\hline DERIV & $\begin{array}{l}-0.0112 * * \\
{[-2.338]}\end{array}$ & $\begin{array}{l}-0.0109 * * * \\
{[-3.888]}\end{array}$ \\
\hline LOANS_REAL & $\begin{array}{l}0.1354 * * * \\
{[5.508]}\end{array}$ & $\begin{array}{l}0.0704 * * * \\
{[3.857]}\end{array}$ \\
\hline LOANS_DEP & $\begin{array}{l}3.5419 * * \\
{[2.809]}\end{array}$ & $\begin{array}{l}3.5678 * * * \\
{[3.744]}\end{array}$ \\
\hline LOANS_AGRIC & $\begin{array}{l}0.4034 \\
{[1.297]}\end{array}$ & $\begin{array}{l}0.0303 \\
{[0.142]}\end{array}$ \\
\hline LOANS_COMM & $\begin{array}{l}0.0480 \\
{[0.754]}\end{array}$ & $\begin{array}{l}0.0733 * * \\
{[2.278]}\end{array}$ \\
\hline LOANS_IND & $\begin{array}{l}0.1839 \\
{[1.774]}\end{array}$ & $\begin{array}{l}0.1102 * * * \\
{[3.675]}\end{array}$ \\
\hline LOANS_FOREIGN & $\begin{array}{l}30.7643 * * \\
{[2.326]}\end{array}$ & $\begin{array}{l}45.3688 * * * \\
{[5.888]}\end{array}$ \\
\hline SI & $\begin{array}{l}-31.8133 * * \\
{[-2.465]}\end{array}$ & $\begin{array}{l}-16.9241 * * * \\
{[-3.601]}\end{array}$ \\
\hline NI & $\begin{array}{l}0.3250 \\
{[0.469]}\end{array}$ & $\begin{array}{l}-0.3754 \\
{[-1.656]}\end{array}$ \\
\hline CAPITAL_RATIO & $\begin{array}{l}-0.0018 \\
{[-1.322]}\end{array}$ & $\begin{array}{l}0.0009 * * \\
{[2.538]}\end{array}$ \\
\hline REV_REPO & $\begin{array}{l}0.5490 * * * * \\
{[3.306]}\end{array}$ & $\begin{array}{l}0.0912 \\
{[0.400]}\end{array}$ \\
\hline Quarter Fixed Effects & YES & YES \\
\hline Bank Fixed Effects & YES & YES \\
\hline Observations & 1,458 & 1,458 \\
\hline R-squared & 0.939 & 0.964 \\
\hline
\end{tabular}

Table 15: Results for the substitution effect between repos and deposits post-BAPCA. For this analysis our sample consists of only those banks which increased their repo agreements post-BAPCPA. In regression (1) the dependent variable is the amount of deposits standardized by total assets while in regression (2) the dependent variable is the amount of deposit over the sum of deposits and repos. POST is an indicator variable that takes the value of 1 for the period 2005q4 - 2006q4 and 0 for the period 2004q1-2005q1. All other variables defined as in Table 9. *, ** and $* * *$ denote significance at the $10 \%, 5 \%$ and $1 \%$ level of significance respectively. Robust t-statistics shown in brackets. 